\title{
INTERNATIONAL CORPORATE SOCIAL RESPONSIBILITY: A CASE STUDY
}

\author{
By \\ Katherine Garcia, B.Com
}

A thesis submitted to the Faculty of Graduate Studies and

Research in partial fulfillment of the requirements for the degree of Master of Business Administration

Eric Sprott School of Business

Carleton University, Ottawa

Ontario, Canada 


$\begin{array}{ll}\begin{array}{l}\text { Library and } \\ \text { Archives Canada }\end{array} & \begin{array}{l}\text { Bibliothèque et } \\ \text { Archives Canada }\end{array} \\ \begin{array}{l}\text { Published Heritage } \\ \text { Branch }\end{array} & \begin{array}{l}\text { Direction du } \\ \text { Patrimoine de l'édition }\end{array} \\ \begin{array}{l}\text { 395 Wellington Street } \\ \text { Ottawa ON K1A 0N4 }\end{array} & \begin{array}{l}\text { 395, rue Wellington } \\ \text { Ottawa ON K1A ON4 } \\ \text { Canada }\end{array} \\ \end{array}$

Your file Votre référence ISBN: 0-612-99019-2

Ourfile Notre référence

ISBN: 0-612-99019-2

NOTICE:

The author has granted a nonexclusive license allowing Library and Archives Canada to reproduce, publish, archive, preserve, conserve, communicate to the public by telecommunication or on the Internet, loan, distribute and sell theses worldwide, for commercial or noncommercial purposes, in microform, paper, electronic and/or any other formats.

The author retains copyright ownership and moral rights in this thesis. Neither the thesis nor substantial extracts from it may be printed or otherwise reproduced without the author's permission.
AVIS:

L'auteur a accordé une licence non exclusive permettant à la Bibliothèque et Archives Canada de reproduire, publier, archiver, sauvegarder, conserver, transmettre au public par télécommunication ou par l'Internet, prêter, distribuer et vendre des thèses partout dans le monde, à des fins commerciales ou autres, sur support microforme, papier, électronique et/ou autres formats.

L'auteur conserve la propriété du droit d'auteur et des droits moraux qui protège cette thèse. $\mathrm{Ni}$ la thèse ni des extraits substantiels de celle-ci ne doivent être imprimés ou autrement reproduits sans son autorisation.
In compliance with the Canadian

Privacy Act some supporting forms may have been removed from this thesis.

While these forms may be included in the document page count, their removal does not represent any loss of content from the thesis.
Conformément à la loi canadienne sur la protection de la vie privée, quelques formulaires secondaires ont été enlevés de cette thèse.

Bien que ces formulaires aient inclus dans la pagination, il n'y aura aucun contenu manquant. 
PAGIRATION ERROR.

TEXI COMPLEIS
ERERUR DE PAGIAAIION.

LE IEXIE EST COMPLET. 


\section{ABSTRACT}

Public expectations and pressure from NGOs and the media are gradually changing the role of businesses. In light of today's emerging global society, more demanding public and corporate frauds, private firms are looking at corporate social responsibility (CSR) as a way to contribute to societal, environmental and economic goals. Corporations have understood the message and are now looking for ways to continue providing value to shareholders while at the same time contributing towards social and environmental wellbeing.

The purpose of this thesis was to examine two Canadian companies operating in two different sectors. The first case study is a company that sells outdoor products. The second case study is also a Canadian company but one involved in the extractive industry. The research is an effort to describe some important areas of CSR, but it is not exhaustive since CSR is a very broad subject. 
To Alex, 


\section{ACKNOWLEDGEMENTS}

I would like to express my deepest thanks to my supervisor Dr. David Cray to whom I feel mostly indebted for his invaluable counseling and help throughout my research. In particular, I would like to mention that his patience and support provided me the motivation to complete this research.

I am also very grateful to the members of my committee, Professor Shibu Pal and Professor Rolond Thomas for their comments and discussions and their support. Special thanks to Dr. Kumar for giving me the opportunity to complete my degree. Many thanks to my friend Cindy Lipman for her recommendations.

My sincere thanks to the representatives of both companies studied for sharing their experiences and challenges with me.

Finally, my warmest thanks to my son Alexander, my mother Cosette, my father Honore, my brother and sister Pablo and Cosette for their affection, consideration and especially patience at all times. 


\section{TABLE OF CONTENTS}

ABSTRACT

ACKNOWLEWGEMENTS

TABLE OF CONTENTS

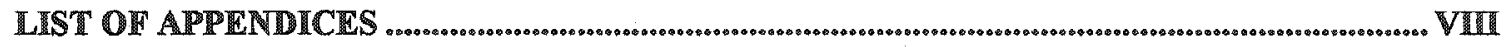

LIST OF TABLES

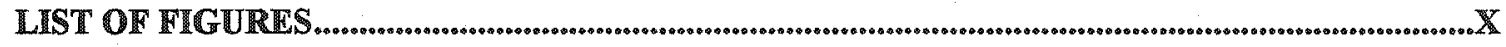

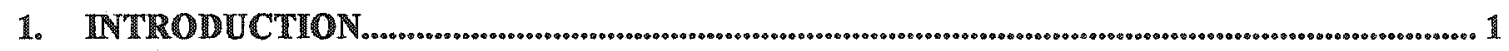

2. ORJECTIVES

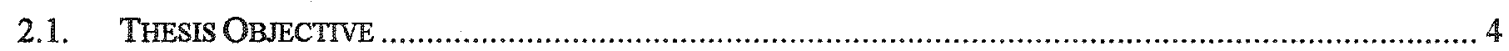

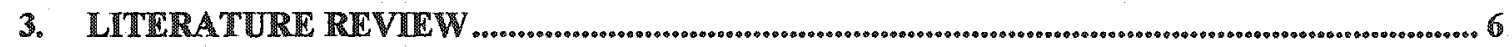

3.1. CORPORATE SOCIAL RESPONSIBUITY, A DEFINITION ……......................................................... 9

3.2. OVERVIEW OF THE EVOLUTION IN CORPORATE SOCIAL RESPONSIBILITY …..................................17

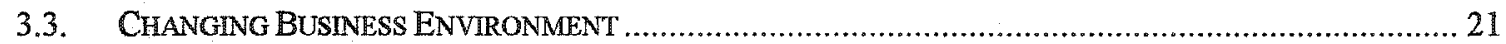

3.4. PRACTICES OF CORPORATE SOCIAL RESPONSIBILTY …........................................................... 24

3.5. RELATIONSHIP BETWEEN CORPORATE SOCIAL RESPONSIBILITY AND COMPANY PERFORMANCE ........ 30

3.6. THE ChaLLENGE OF INTERNATIONAL CORPORATIONS ................................................................... 35

3.6.1 Key steps required by international corporations regarding social responsibility ..........................40

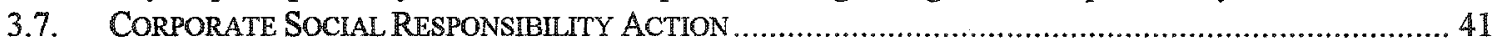

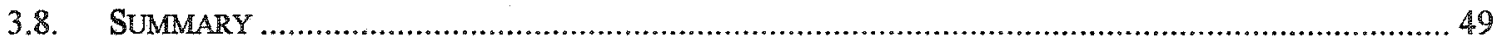

4. RESEARCH DESIGN

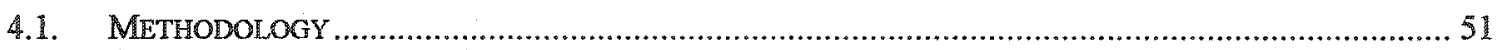

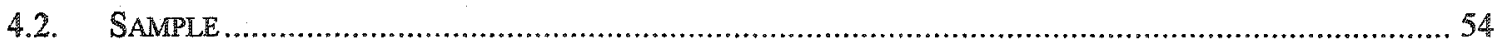

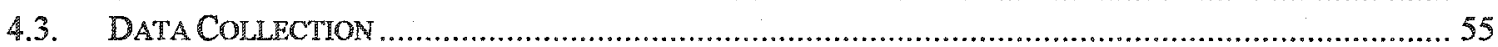

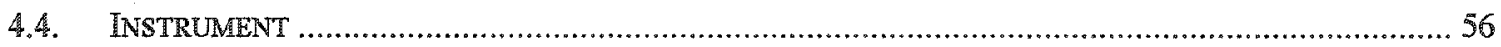

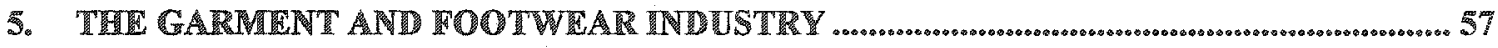

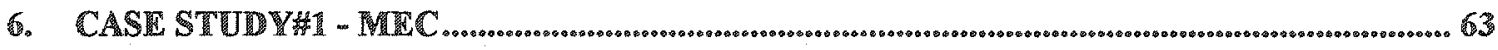

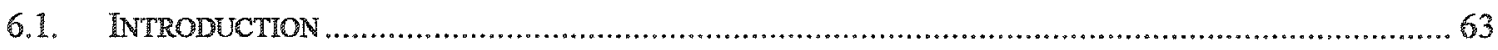

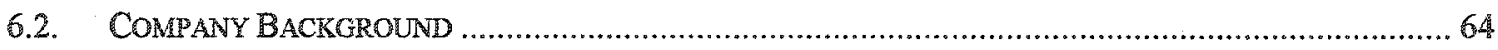

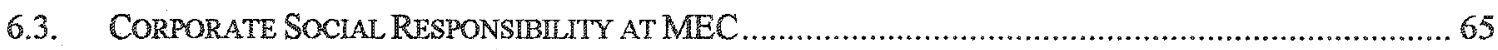

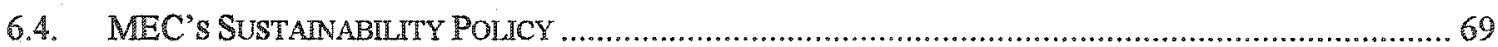

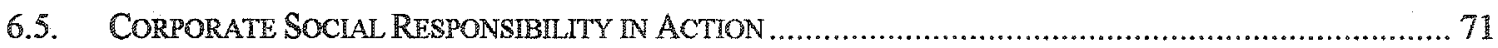

6.5.1 Community-Based Organizations (CBOs) and Enviromental Groups ..................................... 76

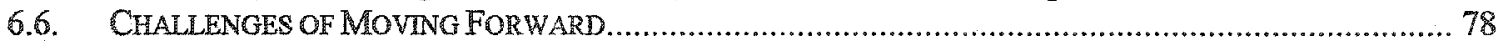

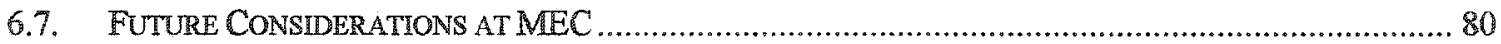

6.8. IMPACTS OF BEING SOCIALLY AND ENYRONMENTALLY RESPONSIBLE ..................................... 82 


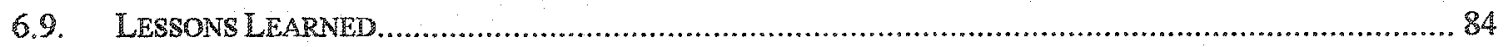

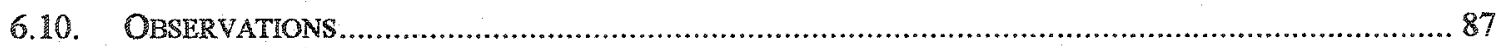

7. THE OLL AND GAS INDUSTRY

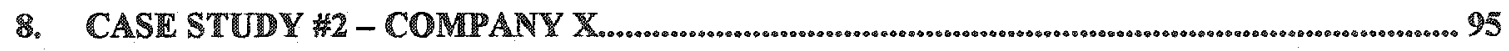

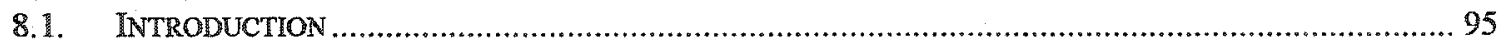

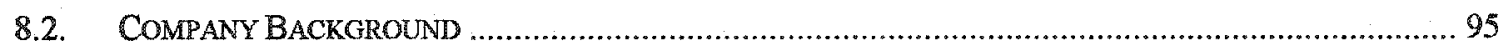

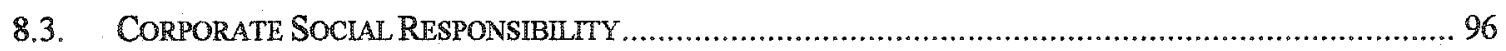

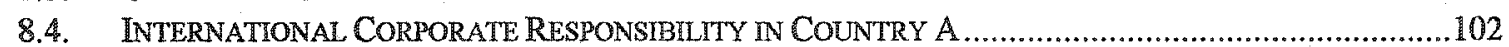

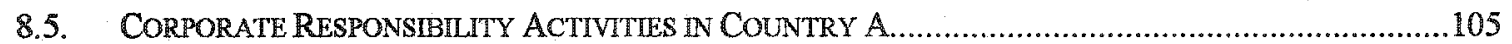

8.6. Challenges OF IMPLEMENTING CoRPoRATE RESPONSIBILITY POLICY ...................................109

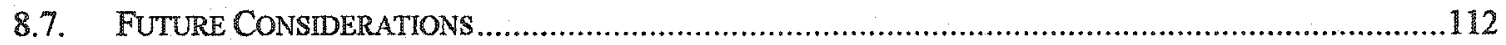

8.8. IMPACTS OF BEING SOCIALLY AND ENVIRONMENTALLY RESPONSIBLE ..................................114

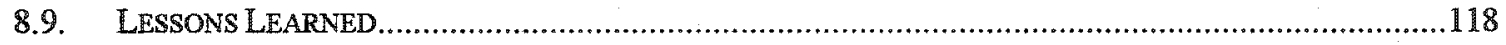

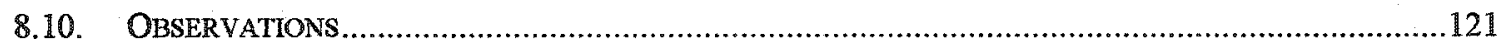

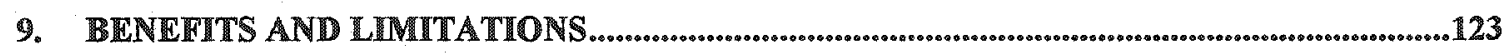

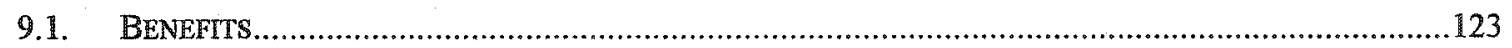

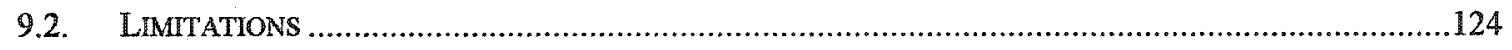

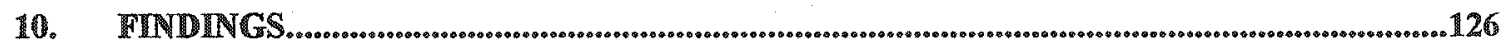

11. CONCLUSION $\ldots$ W.

REIERENCES

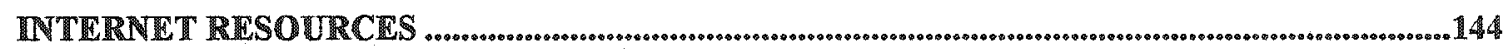




\section{LIST OF APPENDICES}

Appendix 1 - Research Study Process

Appendix 2 - Study Questionnaire 


\section{LIST OF TABLES}

Table $1 \quad$ - Study Methodology by Phases

Table $2 \quad$ CSR Areas for MEC and Company X by Program 


\section{LIST OF FIGURES}

Figure 1 - MEC Business Model 
"Business decisions can profoundly affect the dignity and rights of individuals and communities... It is not a question of asking business to fulfill the role of government, but of asking business to promote human rights in its own competence."

Mary Robinson, 1998

UN High Commissioner for Human Rights

\section{INTRODUCTION}

Companies have been setting up operations in developing countries for numerous reasons, including cheaper labour, new opportunities, and access to resources, all for the ultimate objective of increasing profits. Unfortunately, many of these companies are not following ethical practices or conforming to labour or environmental standards, leading to a global response from concerned citizens (Kapstein, 2001; Cragg and Greenbaum, 2002). Globalization has opened up new opportunities but it has also exposed the world to new risks. Companies are confronted with new dynamics since the linkages between the social, environmental, political and economic roles of businesses are increasing.

Mergers, deregulation and privatization have resulted in the creation of large corporations that in some cases have more economic power than sovereign countries. This has created a shift in responsibility and public expectations towards these corporations have grown. Civil society is demanding more accountability and transparency from public and private

\footnotetext{
${ }^{1}$ In the context of this thesis, civil society refers to a group of organized non-militant people or individuals who work for the benefit of society and the environment. Those not attached to government, and includes media, community based organization, NGOs, and Christian groups.
} 
companies. New factors such as information technology have emerged and are transforming the way companies do business. The former limitations of time and space are increasingly becoming less of an issue. The implications of these changes are affecting businesses throughout the world, in particular large, private, multinational corporations since they have more exposure and visibility.

The challenge for corporations is to maintain and/or increase profits and respond to the new societal expectations at the same time. Managing these two issues, which seem to contradict each other, requires the development and implementation of strategies that will have positive impacts for both the corporation and society. One way of linking economics and social well being is through the development and implementation of Corporate Social Responsibility (CSR) policies and strategies.

There are many definitions of Corporate Social Responsibility which will be examined under the Literature Review of this thesis. As Caroll (1999) notes, the CSR concept has had a long and diverse history in the academic literature. A general view of CSR is for companies to be accountable to their stakeholders. Stakeholders are generally employees, customers, suppliers, communities, etc. Corporate Social Responsibility activities can consist of being responsible to employees, by, for example, developing and implementing policies which improve working conditions for employees in the firm. CSR can also consist of being accountable to the community where the company operates, by, for example, volunteering company personnel to the community. CSR can also involve 
developing policies which are environmentally friendly, for example, setting up a recycling system. The broad understanding is that CSR has 3 principles which represent environmental, social and economic dimensions (Kingston and Wagner, 2004). The terminology for CSR also varies; some companies refer to it as corporate responsibility, social responsibility, corporate citizenship, sustainability, or sustainable development (Overton, 2004).

The case study approach was utilized instead of a more detailed research because it was thought to be more useful by the researcher in obtaining a wide range of descriptive information regarding CSR. This report is divided into five (5) main sections. First, a brief introduction is provided, followed by the presentation of the objectives of the thesis. Second, a comprehensive literature review is provided. The literature review is presented by discussing some of the more important issues concerning CSR, such as its definition, the correlation between corporate performance and CSR and finally focusing more on international CSR issues. The third section provides information on the research methodology. The fourth section consists of presenting the two industries being studied and the two case studies. The final section provides the benefits and limitations of the research, findings and conclusion. 


\section{OBJECTIVES}

\subsection{Thesis Objective}

The objective of this thesis is to contribute to the literature on corporate social responsibility (CSR) by presenting exploratory research using two case studies. A literature review is presented in the first section to provide information on what CSR is and how it has evolved since it was first defined, in addition information is provided regarding international practices and impacts of being socially and environmentally responsible. To reinforce the literature review, two companies operating in the international arena were examined using a case study methodology. The purpose of the case study examinations was neither to judge nor support the companies' practices, but rather provide a general background on the CSR efforts put forward by corporations and to develop lessons learned and understand some of the constraints faced by companies in their attempts to be CSR effective. Two industries were studied to compare approaches and to determine whether there were any differences regarding methodology and CSR departmental constraints.

The research was aimed at providing insight to other companies on "how are companies implementing CSR in the international arena" and contributing to the literature on corporate social responsibility. It was be an attempt to provide insight to questions such as: What works and what doesn't, are they doing anything wrong? How are companies monitoring their investment in CSR? Are they doing anything right that we can learn from?, Are there benefits from being socially responsible?, Are there any generalizations? The case studies will allow the readers to understand the lessons learned from two 
international companies working in outdoor products and services and the oil and gas industry.

The general areas that were identified included;

1. Identification of CSR strategies and activities undertaken by the companies.

2. Identification of lessons learned.

3. Determining the impact of CSR strategies on the company and the community stakeholders, in other words to determine if there is a relationship between corporate social responsibility and performance.

4. Monitoring of social responsibility; accountability and reporting issues.

5. Corporate implementation issues such as CSR policies and statements, decentralization vs. centralization of decision making in CSR, and senior management involvement.

The case studies examine the areas mentioned in the literature review as they apply to those corporations. At the end of each case study a brief observation is provided. In chapter 10 of the report a comparative evaluation is offered.

The case studies are presented following the main topics discussed in the literature review section of the report. These include the corporation's strategic position regarding CSR, the challenges faced by the people working in the CSR department, their forward looking strategy or position, the relationship between performance and CSR and finally the lessons learned. The case studies are a way to examine and understand the topics discussed and how and if corporations apply them. 


\section{LITERATURE REVIEW}

Societal expectations for businesses have developed over time and there have been periods where they have been more noticeable than others. Traditionally, corporations were viewed as a means of obtaining products, services and employment. Increasingly however, the public are demanding environmental and social benefits from corporations. Local and international NGOs and the media are ensuring that public demands and the consequent responsibilities of corporations remain on the agenda. Formal writing on CSR is a product of the $20^{\text {th }}$ Century and references on the subject started as early as the 1930 s, including Bernard's (1938) the Function of the Executive (Caroll, 1999).

In the 60 s issues about minority rights, women's rights, consumerism, environmentalism, corporate support for the Vietnam War and other factors brought about a new cultural revolution in society. These developments initiated the corporate social responsibility movement.

In 1973, Schumacher revolutionized the idea of development and global economics. As an economist he saw the link between society, environment and economics and presented unconventional theories for achieving improved quality of life for people. Schumacher said "The business man, as a private individual, may still be interested in other aspects of life - perhaps even in goodness, truth, and beauty - but as a business man he concerns 
himself only with profits". He challenged the conventional idea that the only responsibility of the enterprise is to make profits. The Corporate Social Responsibility movement was an early response to an article published in 1970 by Friedman stating that the "social responsibility of business is to increase its profits". This argument was challenged and criticized by numerous authors as mentioned in another section of this thesis.

The corporate social responsibility movement grew during a period of public awareness of social and environmental problems and the inability of the government to solve these problems. Schumacher contrasted private enterprises having an "old style" - only profited oriented, and those with an idealistic "new style" - pursuing a number of objectives and taking into account a holistic and more humanistic approach. He linked ownership to the new style approach, indicating that in small businesses, private ownership is natural and just and that in large businesses, private ownership is not just and may be irrational. He presented some examples of how the structure of ownership can be changed to establish a successful business on the basis of collective ownership and socially responsible regulations. In particular he cited the example of the Scott Bader Commonwealth company which was established in 1920 . In 1963 the owner transferred the control of the company to a collectivity and established socially responsible restrictions.

Schumacher's views of idealistic businesses is part of what we call today good business practice, corporate social responsibility, responsiveness, governance, business ethics and 
many other interrelated concepts. It is the movement which makes businesses more accountable and responsible for the quality of life of their stakeholders. In other words these concepts are not new and private enterprises throughout the world had been practicing them before governments began to institutionalize the concept.

The impetus for change is increasing through shifing social values, increasing consumer and shareholder activism, ease of technological communication, strengthening local and international citizen action, depleting natural resources, and a growing recognition that the benefits of globalization are not shared equally, mostly profiting the richer countries.

Wilson (2000) describes the paradigm shift of society's value as a "New Reformation", a reordering of public and private value systems, and sums it up as follows:

- From considerations of quantity (more) to considerations of quality (better)

- From the concept of independence, toward the concept of interdependence (of nations, institutions, individuals, and all natural species)

- From mastery over nature toward living in harmony with it

- From competition toward cooperation

- From the primacy of technical efficiency toward considerations of social justice cha equity

- From the dictates of organizational convenience toward the aspirations of senfdevelopment in an organization's members

- From authoritarianism toward participative management 
- From uniformity and centralization toward diversity, decentralization, and pluralism (Wilson $2000 ;$ p.8).

\subsection{Corporate Social Responsibility, A Definition}

Corporate social responsibility has emerged as the business issue of the $21^{\text {st }}$ century and has been studied for over 50 years. To this day academics do not have a consensus on its definition (Wood, 1991; Carroll, 1991) and it has been frequently assigned to the field of business ethics and conduct.

Publications, definitions and references to CSR started as early as the 1950s. One of the pioneer books on the topic of CSR was written by Howard in 1953, titled the "Social Responsibilities of the Businessman". This was one of the pioneer books on social responsibility for businesses and highlighted a company's role beyond the financial benefits.

Bowen's definition of the social responsibility of businessmen was "it refers to the obligotions of businessmen to pursue those policies to make those decisions, or to follow those tines of relation which are desirable in terms of the objectives and values of our society" (Carroll 1999; p.270). Caroll (1999) argues that due to Bowen's concern with social responsibility and his leadership role in the topic, Bowen should be seen as the father of corporate social responsibility. 
One of the first writers of the 60s who defined CSR is Keith Davies. He argued that CSR refers to 'the firm's consideration of, and response to, issues beyond the narrow economic, technical and legal requirements of the firm" (Davies 1973; p.312). Frederick (1960) was also a major contributor to the emerging definition. He stated, "social responsibility means that businessmen should oversee the operation of an economic system that fulfills the expectations of the people. And this means in turn that the economy's means of production should be employed in such a way that production and distribution should enhance total socio-economic welfare (Frederick 1960: p.60). Social responsibility in the final analysis implies a public posture toward society's economic and human resources and a willingness to see that those resources are used for broad social ends and not simply for the narrowly circumscribed interests of private persons and firms". The definitions of CSR in the 60s were an attempt to link society and businesses, defining society in the broadest terms. There was no specific relation to the ecology, environment, or community.

In the 70s, the number of authors writing and making reference to CSR started to multiply. The idea and inclusion of stakeholders began to appear, Harold Johnston (1971: p. 50) stated that "a socially responsible fim is one whose manogerial staff balances a mulniplicity of interests instead of striving onby for larger profits for its stockholders. A responsible enterprise also lakes into account employees, suppliers, dealers, local communities, and the nation". One of the most important contributions to the definition of CSR was made by the Committee for Economic Development (CED) in 1971, the CED 
articulated a triple concentric definition of social responsibility; "The immer circle includes the clear-cut basic responsibitities for the efficient execution of the economic functionproducts, jobs, and economic growth. The intermediate circle encompasses responsibility to exercise his economic function with a sensitive awareness of changing social values. and priorities: for example to environmental conservation, hiring and relations with employees, and more rigorous expectations of customers for information, fair treatment and protections from injury. The outer circle outlines newly emerging and still amorphous responsibilities that business should assume to become more broadly involved in actively improving the social environment" (CED 1971: p.15).

This definition provides a more integrated approach between the business and employees, society (again as a whole) and the environment.

Eibert and Parket (1973) introduced the concept of community in their CSR definition, using the term "neighbourhood"; "perhaps the best way to understand social responsibility is to think of it as good reighborliness. The concept involves 2 phases. On the one hand, it means not doing things that spoil the neighbourhood, on the other, it might be expressed as the voluntary assumption of the obligation to help solve neighborhood problems. Those who find neighbourliness an owhord or coy concept noy substitute the idea that social responsibility means the commitment of a business or business, in general, to an active role in the solution of broad social problems such as racial discrimination, pollution, transportation, or urban decay". 
Caroll (1979) offered the following definition of CSR "The social responsibibity of business encompasses the economic, legal, ethical, and discretionary (or philanthropic) expectation that society has of organizations at a given point in time".

In the 80 s and 90 s there were fewer definitions but more efforts to measure and conduct research for the purpose of operationalizing CSR. New concepts which were closely related to CSR were introduced; stakeholder theory, business ethics, corporate governance, responsiveness, corporate social performance, and corporate citizenship, amongst others. This caused some confusion in the literature since these concepts are closely related but not necessarily identical.

In an attempt to relate corporate social responsibility, responsiveness and business ethics, Epstein (1987) provided the following definition "CSR relates primarily to achieving outcomes from an organization's decisions concerning specific issues or problems which by some normative standard have beneficial rather than adverse effects on pertinent corporate stakeholders. The nomative correctness of the products of corporate action has been the main focus of CSR". He pointed out that the 3 concepts are closely related and overlap and introduced a new term "corporate social policy process" by merging together his definitions for corporate social responsiveness and business ethics. He stated "the mub of the corporate social policy process is the institutionalization within business organization of the following 3 elements; business ethics, corporate social responsibility and corporate social responsiveness". 
Other more recent definitions of CSR include:

CSR refers to a company's commitment to operate in an economically and environmentally sustainable manner, while acknowledging the interests of a variety of stakeholders and maximizing economic, social and environmental value. It is a holistic concept that can mean different things to different groups and stakeholders. Central to the operations is the belief that both businesses and individuals have responsibilities (Lee, 1997). It's about doing business in an economically, socially and environmentally responsible way - a way that involves all stakeholders including employees, customers and communities. CSR is determined by an organization's policy and continuous action in such areas as employee relations, diversity, community development, environment, international relationships, marketplace practices, fiscal responsibility and accountability. CSR isn't just about philanthropy and volunteerism. It's about having a mindset and a corporate culture that sees value in interacting with society above and beyond simply satisfying customers and shareholders. Some advocates of CSR prefer not to define the term, mentioning that it is more a process than a specific program (Makower, 1992). Another author defines CSR as the measure of a company's impacts on the quality of life of its stakeholders. Thus CSR is the sum of actions taken in the interest of society, the actions which have benefits both inside and outside a company (Brooks, 1986:7). CSR is based on "the legitimacy with society, public responsibility within the organization and managerial discretion by each individual with the organization" (Stanwick P. and Stanwick D., 1998). 
Velasquez (1990) argues that corporations can only act in a very limited sense, and therefore only organizational participants and not corporations can be given moral responsibility. Klonski (1991) argues that businesses should be concerned with doing the greatest good for the greatest number of people. Both arguments demonstrate the importance given to social responsibility, however, Velasquez differentiates between the corporation and individuals working in an organization.

According to Wilson (1997), the "role and responsibility of business extends well beyond the critical importance of wealth creation". He goes as far as saying that "a profitable business sector is vital to funding the standard of living and quality of life to which society aspires". Mclntosh et al (1998) asserts that businesses are socially responsible when they consider and act on the needs and demands of their different stakeholder groups. Finally the World Business Council on Sustainable Development (WBCSD) defines CSR as "The contiming commitment by business to behaving ethically and contributing to economic development while improving the quality of life of the workforce and their families as well as of the community and society at large" (Watts and Holme, 1999).

"CSR is defined as operating a business in a momer that meets or exceeds the ethical, legal, commercial and public expectations that society has of business" (Business for Social Responsibility - BSR). 
All these definitions link the business with societal expectations such as society, environment, employees, and others. In essence CSR should not be seen as the end, but rather as a tool or process to achieve the overall goal of social well-being supported by the corporation, which could be seen as an agent of change.

At the other end of the spectrum of corporate responsibility are the more fundamentalist views of Friedman (1970) and Levitt (1983) who argue that business has only one responsibility and that is to make a profit for its shareholders. Any mission beyond this must be considered fraudulent on the part of the organization's managers. They also believe that corporations function to make a profit and governments should worry about social responsibility. This argument varies considerably with most of the literature and there have been wide criticisms and debates since Friedman published his comments. Using the quote mentioned by the reputable economist Paul Samuelson, Davies (1973), opposed Friedman's view and argued that "a large corporation these doys not only moy engage in social responsibility, it had domn well better try to do so" (Samuelson 1971: p. 24). Chevron Texaco Corporate Chaiman, Dave O'Reilly took a similar view saying that "success is no longer determined solely by traditional financial or operational metrics. Todory, we are held to new standards for corporate citizenship, hman rights, and the enviromment that are no less rigorons than the financial requirement of the investment in communties" (Williams 2002: p.26). Considerable change has occurred since Friedman's comments. Society in general has become more demanding in the selection of products and services and in addition they demand that companies exercise moral judgment towards 
communities, societies and the environment. Friedman may have neglected to understand the change that was occurring at the time and failed to recognize that the move toward CSR was not a gimmick or temporary trend but a permanent cultural change in society.

Finally, API/IPIECA (American Petroleum Institute/International Petroleum Industry Environmental Conservation Association) defines social responsibility specifically for the oil and gas industry "as the voluntary commitment by business to manage its activities in a responsible way. Oil and gas companies aim to be active and responsible members of the communities in which they operate and to contribute to economic development while improving the quality of life" (2003).

The numerous definitions of CSR identified in this section indicate that CSR has evolved from a focused operational concept to a more strategic and global approach encompassing more elements. Initially, the definitions were more limited to the company's immediate environment. Gradually the definition has expanded to include external areas such as stakeholder engagement, community issues and the environment. In other words the definition has evolved from the bottom line to the triple bottom line emphasizing the economic, environmental and social responsibilities of furms.

Corporations seem to agree that CSR has social, environmental and economic issues which are interlinked. Environmental issues in general relate to mitigating impacts on the environment, reducing environmental risks and minimizing the environmental footprint. 
Economic issues consist of creating value for stakeholders, for example, through jobs and royalties. Social issues cover improvements to local communities through, for example, community investment, use of local suppliers, capacity building, and stakeholder engagement amongst many others.

The changes in the definition are a direct result of civil society demanding improved results and accountability of historical inappropriate corporate behaviour. There is a recognition that businesses need to be accountable for their operations and impacts their businesses have on society and the environment. In addition, through mergers, some corporations are more profitable and financially viable than some developing countries and thus the pressure of social and environmental welfare has been transferred to these multinationals.

\subsection{Overview of the Evolution in Corporate Social Responsibility}

The emergence of accountability, governance, responsibility and transparency for the private sector has created different approaches to social responsibility and business conduct. In the era of President Johnson in the United States, the phrase "quality of life" was introduced and changed the whole significance of consumer products and consumerism. The notion of quality products, quality of working life and quality of the environment became issues for the public and corporations had to react to this new trend by introducing products that were safe. Certain business sectors such as nuclear power and tobacco started to be questioned. There was recognition of the need to have 
ecological, environmental, economical and social balance which meant that the private sector was seen as the actor to bring solutions to these consumer concerns. Companies started to create and publish new policies and expand internal training and communication programs to promote compliance. They started to lobby to influence public opinion and the government. Some companies initiated "catching-up" initiatives such as establishing equal employment opportunities for minorities.

Large corporations began to go public about corporate social responsibilities and publish some of their efforts, but they also made public that "any approach to corporate responsibility must begin with the practical recognition that the corporation must be profitable enough to provide shareholders a retum that will encourage contimuation of investment" (Wilson 2000: p.12).

Some companies like Abt Associates introduced the concept of social accounting, an attempt to put dollar figures on social performance. This did not lead to success since it was criticized by both opponents and advocates who viewed it as a gimmick rather than a sustainable approach to doing social business (Wilson, 2000).

More successful initiatives included the incorporation of social issues in the company's traditional annual reports. General Motors used a successful strategy in 1971 inviting educators and representatives of foundations and invesiment institutions to a conference to explain the progress made by General Motors in areas of public concern and obtain 
participants' comments. The comments and conference discussions were published and to this day General Motors has continued reporting on environmental, health and safety issues.

However, it was not until the late 1970 's that companies began to react more proactively to corporate social responsibility issuing affirmative action guidelines, for example, for women's rights and including corporate social responsibility in strategic planning, which required companies to include all stakeholders, consumers, shareholders, employees, community and the general public. Some companies established board of directors' committees to deal with corporate responsibility issues. Others established staff groups to examine and raise questions related to these issues. The Business Roundtable documented some policy instruments introduced by companies, which included;

- A written code of conduct.

- A written policy on disclosure.

- Well-defined corporate policies with regard to such matters as executive compensation, fair pay, equal employment opportunity, personal privacy and freedom of expression.

- A continuing focus on corporate impact on the environment, health and safety in the workplace, and the impact of plant openings and closings on communities and employees.

- Continuing concem about product quality, acceptable pricing policies, and ethics in advertising. 
- A high priority for high level attention to the size and direction of corporate philanthropy.

- A program designed to inform, sensitize, and train present and future management to deal with public policy and corporate responsibility issues (The Business Roundtable, 1981).

Companies like GE adopted systems approach to business/society issues and new corporate responses such as;

- Making a multinational, interdisciplinary analysis of the problem, its impacts, and its solutions.

- Examining both the internal and the external environments of the company in an effort to relate the company to the society of which it is a part.

- Identifying the opportunities as well as the threats inherent in the developing situation.

- Using the basic management principles of goal setting, accountability, and measurement of performance in meeting the new rules.

In the 1980's the issue of corporate responsibility gained force in the United States and the United Kingdom as a result of corporate collapses, corporate raiders, business frauds, increased globalization, society turning to business to engage in finding solutions to societal problems and increased mistrust of the public in the honesty of large corporations. Issues concerning governance, transparency and accountability emerged more strongly. Today, the new rules of the game consist of highlighting corporate social responsibility 
which has been shaped by past progress and rules of conduct which have been adapted to reflect today's more challenging public.

\subsection{Changing Business Environment}

Many believe that the world situation has deteriorated over the years, the poor are getting poorer and the rich, richer, thus widening the gap between different segments of society. Although attempts have been made to decentralize government decision-making, streamlining and efficiency have taken over and mergers are increasingly being formed with governments at the grassroots community level. Governments are cutting public expenditure, affecting safety, education and health. There are uncertainties about the government's ability and commitment to protect its citizens and expectations are growing amongst the public, demanding accountability and transparency from private enterprises. With the uncertain role of the government, local communities are seeking out new partnerships with the private sector. This situation is creating a substantial demand for responsible practices, products and services as well as social demands of government support for business action. Although there are few regulations regarding CSR, there are guidelines, principles and codes of conduct, in particular for large multinationals. These include World Bank (WB) guidelines for international corporations, the International Financial Corporation (IFC) guidelines for environmental and social management, the United Nations (UN) Global Compact and the Global Reporting Initiative. These initiatives have been put in place to assist companies to develop internal principles, policies and guidelines regarding social and environmental commitment. 
In Canada, the Conference Board of Canada and the Export Development Corporation have recognized the responsibility of private enterprise and the need for them to get more involved in the communities they operate and provide a safe and enjoyable work environment for employees. A study published by the Conference Board of Canada in 1996 describes how companies can undertake business in a manner which is beneficial for the business and the communities where they operate. The Conference Board of Canada defines CSR as "Corporate Social Responsibility is the overall relationship of the corporation with all of its stakeholders. These include customers, employees, communities, owners/investors, government, suppliers and competitors. Elements of social responsibility include investment in community outreach, employee relations, creation and maintenance of employment, environmental stewardship and financial performance" (The Conference Board of Canada: Internet research).

According to Ethical Funds Inc, the vast majority of Canadians feel that companies should treat their employees well, should have good relations with their communities, should not pollute the environment and should be taking active steps to improve environmental performance (Ethical Funds Inc. - Internet research). These kind of expectations are not only occurring in Canada but it is a worldwide change facilitated by information technology. In addition, more demands are being put recently on corporate governance following corporate collapses such as Enron Corp., and WorldCom Inc. It is no longer enough for companies to provide safe products and services and employment but civil society and governments are demanding that corporations contribute their economic 
growth towards environmental well being and quality of life for people living in the communities where companies operate. As quoted by David Thompson, CEO \& Deputy Chair of the Board, Teck-Cominco Ltd., "Companies are responsible to their shareholders to produce an adequate rate of retum through activities which are lawful, environmentally sound and morally acceptable. By fulfilling this responsibility, a corporation can sustain its operations, reward the support of it shareholders and contribute the moximum possible to society's well being".

Some companies in Canada are also part of what is called Socially Responsible Investing (SRI) defined by Ethical Funds Inc. as the integration of social, ethical and environmental values into the traditional process of making buying and holding stocks investment decisions. In order to be considered part of the Ethical Fund, companies go through a screening process. For example companies cannot be from tobacco, nuclear power or military industries. Secondly, companies are reviewed qualitatively to identify if they encourage community, shareholder and employee relations, human rights efforts and leadership on environmental issues. Canada has also set in place the Jantzi Social Index fund which tracks 60 Canadian socially responsible stocks (The Jantzi Social Index: Internet research).

The Canadian firm Ethicscan uses a rating system to assess the CSR of Canadian companies. Under the criteria used by Ethicsan, Imperial Oil Canada owned by Exxon is the most socially responsible company in Canada. This is an indication that Ethiscan 
evaluates companies but not their industry, which might be unsustainable or ecologically unsound and indicates a need to dig deeper into the activities of companies. CBSR (Canadian Business for Social Responsibility) also agree that many companies involved in less socially acceptable industries such as mining and oil and gas are heavily involved in CSR.

\subsection{Practices of Corporate Social Responsibility}

According to Adine Mees, president and CEO of the Canadian Business for Social Responsibility (Mees: 2004 meeting in UBC), a company moves from a scale of thin commitment to thick commitment in CSR; from commitment, policy, program, program evaluation and measurement, stakeholder involvement, to accountability and transparency which is the strongest commitment. CBSR is a Vancouver based not-for-profit membership organization of for-profit businesses committed to socially responsible policies and practices that actively improve the quality of life of communities. CBSR has identified 6 basic stakeholders;

- Communities

- Employees

- Customers

- Suppliers

- Shareholders

- Environment 
The Canadian Business for Social Responsibility (CBSR) asserts that there are a number of trends occurring in Canada regarding CSR, which include, but are not limited to (CBSR - Internet);

- Reporting; increasing private companies' CSR reporting to earn stakeholder trust.

- Government support; the Government of Canada is passing more bills to support CSR activities. In particular, there are four federal departments which are more committed to CSR, these are Environment Canada, Industry Canada, Foreign Affairs Canada and Natural Resources Canada.

- Sustainable investment trend; there is an increase in social fund investment. Canada currently has approximately 45 mutual funds in social investment.

- Consumers; ethical consumers voting with their dollars.

- Growing public demand; NGOs and citizen groups are increasingly being more demanding.

Another trend appearing in the literature (Fliess, 2001) is the increasing dialogue between stakeholders. Companies are augmenting their discussions with labour unions, environmental groups and other relevant stakeholders and the implementation of certification solutions by corporations, which is the establishment of codes of conduct (Kapstein, 2001), monitoring and reporting. According to the State of Global Environmental and Social Reporting, which evaluates the reporting of the 100 largest 
companies from Fortune Magazine's Global $500,50 \%$ of the world's largest companies produced environmental and social reports in 2001, an increase from previous years.

The Dey Report asserts that the responsibility for good governance rests with the senior executives and the board of directors of the company. The report provides a set of recommendations for senior executives, including the recommendations that the board of directors should take a leadership role in establishing and monitoring compliance with the firms' code of conduct or statement of values (Dey, 1994). In other words, senior officials need to mainstream corporate social responsibility in the company's polices, statements, code of conduct etc. Senior management has to be committed to the cause. Without this commitment there is little foundation for CSR and lack of long term sustainability. An organization's principles of integrity and ethical values are part of the company's corporate culture. It represents a systemic change in organizational direction. Senior executives need to publish their codes of conduct or policies and ensure that all employees understand this code. This is the first step, but they also need to ensure that this code of conduct is implemented and is not merely a statement to which employees provide lip service. The codes of conduct can include information about the expectations of the firm and can address guiding values and principles including workplace and product safety, environmental responsibility, employee privacy, confidentiality of information, discrimination, equal pay, community and social commitment, etc. The codes of conduct need to be integrated into the company's organizational culture and become part of the way the company does business. Equally important is briefing employees to make sure 
they understand the codes of conduct. In addition, supervision, enforcement, and followup are required to determine if changes are needed.

Kingston and Wagner (2004) suggest that leadership on sustainability and CSR are important to set priorities and to ensure that commitments are achieved. They separate leadership from a high strategic level to operational leadership; leadership by industry as a response to external pressure, leadership by the board of directors to determine company policy and values, leadership by the CEO as the principle champion, executive committee leadership to provide advice, delivering results and communicating progress to the board, business and functional managers to drive the process, operational managers to deliver performance and finally contractors to adopt and actively deliver the company's objectives.

Large companies today have well-established codes of conduct or guidelines for staff on how to behave if confronted with bribery, conflict of interest, gifts, etc. But increasingly companies are establishing rules on good behaviour; respect for labour rights, clean environment, preservation of natural resources, respect for the community, personal freedom, etc. MNEs are in particular concerned with codes of conduct, and efforts have been made in setting up EHS (environmental, health and safety) policy statements. For example, mining, forestry and paper companies focus on rules of behaviour for environmental management and health and safety standards. Labour standards are common in garment, footwear, rug and sporting goods industries (Fliess, 2001 and 
Gereffi, Johnson and Sasser, 2001). Some companies have developed CSR programs as part of their EHS structure, whilst others have separate departments to deal specifically with CSR. These functions are usually part of the corporate office or department. (Overton, 2004).

Taking action on CSR begins with recognizing that it is a strategic issue that penetrates all aspects of corporate behavior, it is integrating social and economic missions in business planning and operations. CSR must be considered a core value of the company. According to Charhon, the D.G. of the Fondation de France, the first step in CSR is developing a strategic plan and internal acceptance on the part of the board members, shareholders, and employees and incorporating it in the long-term corporate strategy. CSR requires a mindset that is in tune with the society and community in which the company lives and is making a living. This means that companies show their commitment and take action by working towards the following three areas: corporate practices and standards, community involvement, and related human resources and management practices (CBSR). Lee (1997) identifies three areas which are within the scope of a firm's regular business activity, operations (e.g. taking care of employees), environment (e.g. how it deals with pollution) and the role it plays in the community in which it operates. Taking action means identifying and adopting management practices that integrate socially responsible activities into the daily process of doing business. 
Companies wanting to take strategic actions on corporate social responsibility face many challenges since strategic research, preparation and planning is required to determine where a company can have the most impact and ensure that efforts are not wasted. Lack of planning could lead to efforts being made in areas that are not required by stakeholders or to activities that do not match the corporations' goals. Without research and preparation, limited financial and human resources could be invested in areas that do not contribute to the corporation's image and reputation. In addition, the change from shareholders to stakeholders has widened the target since stakeholders consist of employees, shareholders, consumers, communities, NGOs and the general public. Planning for large audiences with many different needs requires strong leadership, commitment and vision. The importance of stakeholder definition has been widely stated in the academic literature, for example Wheeler et al (2002), De la Cruz and Garcia-Falcon (2002), Cragg and Greenbaum (2002), and Kapstein (2002).

Corporations wanting to be more socially and environmentally responsible have a number of options, they can delegate the task to a strategic company manager or hire a consultant or a permanent staff to deal with this issue. Corporations wanting to invest in the community where it operates can work in partnership with civil society organizations such as non-govemmental institutions which have years of experience dealing with social and economic issues. Deciding on which approach to take is unique to each company, depending on its sector, the location of the company, management structure, outputs and its stakeholders. The OECD encourages corporations to involve their employees 
worldwide in a corporate vision and mission statement that promotes sustainable growth and improved quality of life, for all countries, for all employees, regardless of locations. However, whatever the direction the company wishes to take, it needs to understand that corporate social responsibility is not charity, it is a strategic long-term initiative that requires financial support and company commitment. The most important thing is how a company does its activities and business, how it deals with its responsibilities to internal stakeholders and the values and commitments it places on the corporate codes and guidelines (OECD, 2000). Finally, the companies need to establish monitoring programs to determine the impact of CSR initiatives, and best practices. Case studies and lessons learned need to be recorded and shared throughout the corporation. In the absence of monitoring systems, some companies have added penalty systems such as aggressive enforcement for offenders of the company's code of conduct.

\subsection{Relationship between Corporate Social Responsibility and Company Performance}

The interest in whether socially responsible firms were also profitable grew in the 80 s and research on the topic started to appear in academic circles. Cochran and Wood (1984) were two of the first in operationalizing the idea and surveyed companies using the Moskowitz Reputation Index. This index categorized firms according to "outstonding", "honorable mention" or "worst", although they admitted that the index was a weak CSR measure. 
There are mixed results on the relationship between financial and social performance (Stanwick, P. and Stanwick S., 1998). Bowman (1978), Fry and Hock (1976), Preston (1978), Anderson and Frankle (1980), Belkaoui (1976) have all identified a positive relationship. However other studies cited by P. Stanwick and S. Stanwick (1998) have found a negative relationship and that "the costs of being socially responsible forces the firm into an unfavorable financial position versus those that are not socially responsive".

Gragdon and Marlin (1985) argue that high responsibility results in additional costs that position firms at economic disadvantages compared to others that are not socially or environmentally responsible. This can be true in the short term, since there are financial costs associated with being socially responsible. McGuire, Sundgren, and Schneeweis (1998) claim that concern for social responsibility may limit a firm's strategic alternatives. This assumes that socially responsible firms have alternatives that are less financially viable and less competitive. On the opposite side lying, cheating, and dishonesty can lead to short-term profits. However, these are short-lived and most business leaders would agree that corporate activity is dependent on trust and cooperation (Wesley, 1997).

Aupperle et al (1985) and Abott and Monsen (1979) did not find a significant relationship between CSR and profitability. However, Parket and Eilbirt (1975) found that on four separate measures of firm profitability; absolute net income, profit margin, return on equity, and earnings per share, the CSR firms proved to be more profitable in the long- 
term. Similarly, Macmillan (1996) found that social considerations in the investment process can enhance the possibilities of economic return.

A 1995 report released by Ernst \& Young showed that companies that invest in CSR are more profitable than those that do not. This includes investments in environmental controls, community development, worker training and coaching, customer service and responsible citizenship. Similarly a study of 130 North American firms showed that companies contributing to social causes performed the best financially (Wokutck and Spenser 1996).

It is difficult to determine and measure if a specific social and environmental activity undertaken by a firm produces benefits for the company. For example, if a company implements a strong community relations program and there are no community labour strikes, can this be attributed to the community relations program? A company that adopts a comprehensive social employee program might benefit from lack of labour disputes, low labour turnover and other labour related benehits. However, it is difficult to make a correlation between the employee program and financial performance.

According to Kingston and Wagner (2004) there is little doubt that there is a correlation between CSR management and stock market performance and no clear distinction between "companies that perform well are generally strong in CSR" and "componies that are strong in CSR generally perform well". For example, companies that obtain high 
financial performances might be more willing to invest in social activities since they have funds to implement these kind of programs. However, the financial performance cannot be attributed to the social programs since high financial performance was there before the social behaviour.

Corporate reputation has been linked to financial performance and attracting job candidates (Fryxell and Wang 1994; Gatewood, Gown and Lauteenschlager 1993). In addition, CSR can act as a public relations tool and result in improved public image and goodwill from stakeholders (Riordan, Gatewood and Bill, 1997). Benefits can be derived from attracting quality job candidates, customers and employee loyalty. Free publicity can be generated from both good and bad actions. A company that finds itself in the center of positive media attention can benefit from an improved image. The opposite is true for corporations receiving negative media attention (Robins and Reidenbach 1989), in fact the impact of bad publicity results in more damage due to the media tendency of exposing controversial practices longer than positive practices. Good corporate practices can protect corporate reputation, improve employee morale, enhance consumer and client loyalty and avoid costly criminal and civil proceedings (Fleiss, 2001). Fleiss also warns that companies that do not practice what they pledge risk adverse publicity, loss of customers, and being black listed by stakeholders.

Kotter and Heskett (1992), Collins and Porras (1995), Waddock and Graves (1997), and Roman et al. (1999) have all concluded that there is empirical evidence suggesting a 
positive correlation between stakeholder inclusive, socially responsible business practice and business performance.

The Canadian Business for Social Responsibility (CBSR) points out that there are a number of business cases for corporate social responsibility, including; reputation management, employee recruitment and retention, competitiveness and market positioning, operational efficiency, license to operate and risk management.

CSR can help to create an overall healthy work environment which can lead to more motivation and improved efficiency and productivity. It is unlikely that workers that feel good about working with a morally responsible firm which treats their workers fairly will not be loyal and committed to the company. According to Simms (1994), morally responsible firms report fewer losses due to employee theft, expense report fraud, employee sabotage, sexual harassment and employment discrimination. This suggests that there is a correlation between financial performance and reputation and ethical principles.

Today, with more and more companies looking at CSR, some of the perceived advantages cited by advocates include:

- Attraction of quality employees, employees care about who they work for

- Increased employee loyalty

- Increased employee pride, satisfaction and productivity 
- Enhanced govermment relations, which can affect outcomes of regulatory decisions, negotiations on tax issues, and license renewals

- Increased client loyaity, clients connect contracts to values

- Promotion of networking opportunities with key stakeholders that can lead to business opportunities

- Less volatile stock value, investors are looking for socially responsible companies

- Free publicity

- Increased public image and thus improved reputation

- Reductions in operating costs

- Costs for legal and insurance matters are reduced, and relations with activist groups improve

- Risk management tools, having a CSR program can reduce delays and unanticipated events (Overton, 2004).

It is clear from the above discussion that many of the advantages of having a CSR program fall under the category of intangible assets and thus are hard to measure. However, it is reasonable to say that a CSR program is a valuable asset for a corporation.

\subsection{The Challenge of International Corporations}

Globalization, expanded interconnectedness of markets and citizens and technology have brought about new challenges for today's international corporations drawing attention to the power of business in social, environmental and economic impacts. Information 
technology has reduced information barriers and has allowed the public and civil society in general to have easy access to information that was not available a few years back. Information about other countries' human rights, worker's abuse and problems in general are now easily accessible through rapid media such as satellite TV and the Internet. This has resulted in greater freedom of speech and demands for greater accountability from governments and businesses alike. Civil society in developing countries have been exposed to information regarding their rights and what to do to protect their rights. Support from countries in the West has allowed civil society groups to lobby for human rights compliance. In addition, the media in developed countries have exposed some of the issues and problems caused by government and multinationals allowing civil society in these countries to express their position more freely.

As noted by Johnston, Secretary-General of the OECD in his keynote address to private organizations and non-governmental organizations, "Globalization is an irreversible process, and at the heart of that process is business" (OECD 2001: p.7). The expansion of international business, supported by information communication, technology, transportation and so on, is driving economic integration. De la Cruz and Garcia-Falcon (2002) observe that in order to survive and be successful companies in today's global and complex environment need to think in wider strategic terms and include social, political and ecological elements in their strategies. Hosmer (1994) goes further and adds that the success of companies operating in global competitive economies depends on a large 
number of stakeholders to whom the company must make commitments if they wish to survive.

According to Wilson (2000) and Kapelus (2002) globalization is raising the level of commonality in expectations between one country and the next as the "best societal practices" of corporations become globally known and standardized. It also increases awareness of global problems such as population, environment and the division of economic resources driven by corporate scandals like Bhopal in India, various oil spills such as the Exxon Valdez, repeated discoveries of sweatshops in Asia and recent corporate fraud in the USA. Another factor contributing to the interest in CSR is the increased organizational capacity of NGOs, indigenous groups, and social movements.

There is substantial research on ethics and corporate social responsibilities in their application of business conduct and company policies in regards to workers and affected communities. Companies are finding themselves in the center of public criticism that questions their ethics and business conduct. It is affecting companies from all sectors, from garment to oil companies. The new social paradigm has affected both national and international companies, but when companies move their operations abroad, it is even more challenging from an ethical perspective. The public in general will support less from foreign companies. Companies that have moved their manufacturing abroad to secure cheaper labour are more susceptible to criticism since they tend to be led by economic factors solely. There are public outcries over companies that have abused workers, 
employed children, and harmed the physical environment. It is a new era and companies have understood the importance of linking profits with ethical business practices. Today, many companies are faced with numerous legal, regulatory, cultural and business environments, making the challenge of legal and ethical compliance more complex. According to the OECD (2001) many large corporations, especially multinationals, are joining the corporate social responsibility movement. Some are doing it for cynical reasons to protect their brand image, others because they understand that they must take responsibility for the behaviour of their subsidiaries and suppliers.

Corporations and their social responsibility are considered global issues, but they have local applications. Corporations need to think globally but act locally to avoid problems. Companies operating globally are operating in an environment where there are differences in values, ethics, and culture. They need to be careful since there are practices that are considered ethical in one country and unethical in others. Should the companies operate in a manner which is ethical by Western standards or local standards? Are there any international rights or wrongs? This is a dilemma facing many companies today. A common example is the practice of hiring children. For Western standards and the Westem public this is not acceptable. Lobbying from the Westem public has resulted in a decrease of working children. This practice, however, is not understood by the local public who believe that working children contribute to the family income and also take the children out of the street. Even worse the children might be then forced to work for local companies, which, in some cases, might have worse labour standards. Consumers in 
Western countries will question practices of companies based on their beliefs and values and may impose their values and ethical standards on companies operating in a foreign country assuming that this is the required business behaviour. It is not clear what is the best practice. It is all based on a difference of perspectives. An example of a positive outcome resulting from Western standards being applied to local countries is embodied in the Sullivan Principles. These principles were a direct result of increased controversy surrounding US companies' involvement in South Africa. The principles covered issues regarding non-segregation of all facilities, equal pay for equal work, equal employment practices, initiation of training programs for non-white workers, increased numbers of non-whites in managerial positions, and improved quality of life for employees outside of work in areas such as housing, education, and health. The principles were developed in the US and, although they went against the South African Apartheid Policy which discriminated against the black South African people, the adoption of the Sullivan principles by US corporations working in South Africa resulted in decreased endorsement of apartheid rules in South Africa by US subsidiaries. (Donaldson \& Gini, 1990).

CSR is a common topic in the international arena. Govermments have begun the process of institutionalizing CSR in corporations which is an indication of the importance given to the topic. The International Labour Organization (LO) and the Organization for Economic Co-operation and Development (OECD) have developed and established, checklists and principles on CSR. The OECD developed Guidelines for Multinational Enterprises to promote corporate transparency and accountability. 
The World Business Council for Sustainable Development believes that companies should first determine their mission and then integrate corporate social concerns into their business strategy. They argue that companies should focus on individuals (individual employees, managers and citizens) and should leave a corporate legacy by instilling ethics of education and learning, put employees first as business" best assets and ambassadors, and also know their neighbors, both their communities and cultures, establish a system for keeping CSR debates and dialogues transparent and continuous, form smart partnerships, measure and account for what they do, and report externally to reach all stakeholders.

\subsubsection{Key steps required by intemational corporations regarding social responsibility}

The literature on intemational CSR indicates that some of the most important aspects of CSR are ensuring that senior management is committed to CSR, developing a social responsibility strategy, internal acceptance on the part of board members and shareholders of the strategy and developing a global social strategy in consultation with field offices since the applications are made at the local level. In addition, head offices should express a global social mission with a declaration of social responsibility at the subsidiary or field level (Thompson and Strickland, 1994). Chris Marsden (OECD 2001) argues that there are three main points international corporations should look into when attempting to be socially responsible. First is the need to understand that CSR is about the whole business activity, not just about community investment. Corporations need to run their business safely and legally, that is their main responsibility. Secondly, they need to reduce to a 
minimum any adverse impact on the community, society and enviromment, which means setting standards beyond those required by law, and finally they need to make as much as possible a positive impact by addressing social issues which are within their competence of influence, are relevant and can benefit the company as well as the communities.

The following section will discuss CSR actions in the global arena.

\subsection{Corporate Social Responsibility Action}

As mentioned in this thesis, under increasing pressure from citizen groups, multilateral agencies, and regulatory bodies, global firms have taken action to implement socially responsible business practices such as developing codes of conduct, guidelines, policy action, rules, certification arrangements and monitoring and reporting. Also, as noted by Kapstein (2001), Kapelus (2002), and Wheeler, Fabig, and Boele (2002), corporations need to be aware of the social environment in which companies are operating, in particular in the global market, and ensure that the CSR strategy and codes of conduct reflect the local reality. There are numerous examples mentioned in the CSR literature of multinational CSR strategies which were implemented but were not successful or did not have a positive impact in the local environment due to the companies' inability to understand and accept the local situation. In addition, according to Wheeler et al. (2002) there is sill a need to achieve consistency between stated corporate social responsibility strategy and the actual performance. Consequently there is a need for developing 
stakeholder responsive models of CSR which are an integral part of the company's approach to strategy formulation and implementation and the development of competencies consistent with that strategy.

According to Frederick (1991) some of the ethical principles adopted by international companies include; 1) adopting safety and hygiene standards at work and advising the employees of the risks involved in the work they do; 2) respecting every person's rights to life, liberty, security and privacy; and 3) controlling operations that contribute to air and water pollution. Mountain Equipment Co-op, for example, has adopted a sustainability strategy for dealing with social and environmental commitments. This is being done through a 4 pillar strategy which includes; 1) Business operations: developing operations that are environmentally friendly; 2) Product sustainability: things such as adopting human rights guidelines in the supply chain; 3) Sustainable consumption: providing members with SWAP options; and 4) Community involvement. Donaldson and Gini (1990) adds that international companies have to increase the wealth of consumers and employees, respect citizens' rights and minimize the damage or adverse effects in countries where they operate. However, Kapelus (2002) cautions that businesses in general operate within the constraints of profitability and thus budgets and programs developed under the CSR strategy are also affected by this constraint. This points to the need to develop CSR guiding principles, codes of conduct, and activities that will have a mutual benefit for both the company and the communities. 
A code of conduct sets out fundamental guiding principles to steer a company's behaviour in relation to purchasing, proprietary information, workplace safety, environmental responsibility, marketing, intellectual property, confidentiality of employee records, product safety, and employee privacy (Johnston, 1997). Using Levis Strauss as an example, the company has an established core set of values puting emphasis on its relationship with the community and stakeholders. They have four areas of activity with broad and general relevance:

- Philanthropy: This is the process used by Levi to put something back into the community voluntarily. Levi has focused its efforts on supporting HIV and AIDS initiatives, economic empowerment for low-income people, particularly women minorities, working poor and other disadvantaged groups, youth empowerment, and social justice.

- Employee relations: The company has undertaken a number of initiatives to show their long-standing commitment and practice of good behaviour in the conduct of employee relations. Levi believes that commitment to employees is a fundamental characteristic to any commitment to corporate social responsibility.

- Diversity: Levi has played a role in commitment to diversity regarding globalization, which they see as the movement of people and ideas around the globe. They recognize the values and drive the process toward multi-culturism and multi-ethnicism. 
- Relations with developing countries: They have a published code of conduct to govern in an ethical way the business relationships with their contractors in developing countries.

The following examples are best practices of companies undertaking corporate social responsibility programs and their area of concentration;

\section{Foundation Grants - AT\&T}

- The AT\&T Foundation provides grants for education, civic/community and arts \& culture programs. Since 1984 , the company has invested more than $\$ 600$ million in support of education. Currently, more than $50 \%$ of AT\&T's contribution dollars, employee volunteer time and community service activities are directed toward education.

- Created the AT\&T Learning Network, a $\$ 150$ million corporate commitment to support the education of children in schools (grades K-12) across the United States by providing the latest technology and cash grants to schools and communities.

- While the AT\&T Foundation does not grant scholarships to individual students, the AT\&T Labs Fellowship does. Fellowships are available to outstanding minorities and women students who are pursuing $\mathrm{PhD}$ studies in computer and communicationsrelated fields.

- Its LEAGUE Foundation is a scholarship fund, created and run by the LEAGUE at AT\&T. Each year, the Foundation awards $\$ 1,000$ academic scholarships to assist self- 
identified Lesbian, Bisexual, Gay and Transgender graduating high school seniors in attending college.

- Launched in 1994, AT\&T CARES provides cash grants to nonprofit organizations in which AT\&T employees volunteer their time. Cash grants range from $\$ 250$ to $\$ 5,000$.

- AT\&T centers its contributions in arts and culture on innovative projects that collectively create a legacy for the future. The creation and presentation of new artistic work, the exhibition of contemporary art, the celebration of cultural diversity, and the collaboration of the arts and technology are key.

Employee volunteer programs - AT\&T

- AT\&T supports and encourages volunteerism through its AT\&T CARES program. During 1998, over 50,000 AT\&T employees participated in the AT\&T CARES program, contributing over 567,000 volunteer hours to nonprofit organizations in the USA.

- Employees are permitted to spend one paid day a year away from their jobs working at a nonprofit organization of their choice.

Community Support - Chevron

- Chevron commits $12 \%$ of its contributions to civic/community programs.

- Employees participate in the United Way Week of Caring.

- Chevron hosts the annual Nonprofit Day Conference (with Compass Point Nonprofit Services), a full day of seminars and workshops for San Francisco nonprofit 
organizations to provide training and to celebrate their achievements. This event is attended by nonprofit managers.

\section{Environmental Sensitivity - Suncor Energy}

- Strategic planning to avoid using surface water to minimize environmental footprint.

- Suncor takes action to minimize disturbance by planning to reuse the seismic lines for roads and pipelines Research rights of ways (Bechtel Best Practices, 2002; BurstonMarsteller-Internet and SPE Conference, Calgary, Canada - March 2004).

Another aspect mentioned in the literature is the issue of autonomy and delegation of social responsibilities by the head office to the field office or subsidiary. There are contradictory point of views in regards to this subject, for example Kostava and Zaheer (1999) state that more decentralized organizations will find it easier to deal with social challenges, however Blake (1980) proposes that decentralization can produce an abdication of social responsibilities and subsidiaries may focus on areas which might not be beneficial to the society and which do not have head office consent.

La Cruz and Garcia-Falcon (2002) undertook a study to determine the factors explaining the different levels of social response. One of their findings reveals that top management commitment is one of the determining factors of the degree of the subsidiaries' social effort. The authors concluded that as the involvement of top management in the social 
policy increased, the degree of effort aimed at the establishment of the social posture and implementation of social response was significantly superior.

Accountability and transparency is an important step in corporate social responsibility. The method used by companies will vary depending on the sector, size, geographical location etc. and can include reporting, workshops, presentations, internet and other activities. Increasingly, corporations are developing policies and standards to improve accountability and transparency. For example Catholic Relief Services have published the Bottom of the Barrel report which is a request to oil and gas businesses to publish what they pay to governments. This is a way to lobby with other members of civil society to obtain further commitment from oil and gas companies in being more financially transparent. In addition, the OECD has developed recommendations on strengthening corporate governance.

Certification is a tool used by corporations in an attempt to demonstrate good corporate transparency and governance. There are several levels of certification which range from the corporations having more control and power over their rules, regulations, internal compliance verifications to corporations submitting compliance reports to multilateral organizations such as the World Bank. These latter companies tend to be larger corporations and larger investment projects in which multilateral organizations have some leverage on the investment, for example ExxonMobil's Chad Export Project. Gereffi, Johnson, and Sasser (2001) establish that certification is classified under four broad categories; 
- First party certification: This results when a single company develops its own rules and reports on compliance.

- Second party certification: An industry or trade association produces the codes of conduct and implements the monitoring mechanism.

- Third party certification: Involves a third party, such as an NGO, producing rules and regulations and lobbying for compliance from corporations.

- Fourth party certification: Consists of rules and regulation established by multilateral agencies and companies must submit their progress reports to these organizations.

The method used by corporations varies depending on the internal policies of the company and industry. For example, in the case of the forestry sector some companies have adopted internal and industry (first and second party) codes of conduct but under pressure from NGOs and criticism from environmental groups, the industry had to adopt stricter standards which had been developed by third parties (NGOs). It is also noteworthy to mention that there are internal politics regarding monitoring, which can be done by unions, NGOs, or independent monitors. Unions, for example, feel threatened by the legitimacy of the actions of other monitors, are skeptical and believe that the achievements of monitoring groups will make unions seem unnecessary and will discourage union efforts. In addition, external certification might not always lead to benefits to local workers. As mentioned by Kapstein (2002), GAP invested considerable funds in obtaining outside certification which led to better working conditions but also to a lack of wage increase probably due to the investments made by the company to ensure better working 
conditions. Some may argue that working conditions are a "must" for workers, but i⿱ would have been better to consult with workers to determine whether they preferred a salary increase or improvements in working conditions.

Social responsibility doesn't just happen, there needs to be commitment and approval from senior management through a policy statement. For example, Marks and Spencer's policy is to support the communities in which the company trades.

\subsection{Summary}

The literature review has focused on some of the fundamental issues surrounding CSR; a historical definition of CSR from when the concept first started to emerge in the 50s to today's more focused definition, evolution of CSR which looked at different approaches used by corporations when the topic first appeared, changing business environment which has led to today's companies being more responsible to the society and the environment, practices of companies implementing CSR, explaining the relationship between CSR and corporate performance and describing the business case for CSR, introducing some of the challenges faced by international corporations, and finally the last section provides some examples of what corporations are doing in the international arena.

The literature review was presented from a more macro perspective and then gradually narrowing down and focusing more on the international aspects of CSR. The purpose of presenting the information in this manner is to allow the reader to understand CSR and where it is today. The international section on CSR is presented towards the end of the 
literature review and examples of some of the initiatives and activities undertaken by some companies are also provided.

This chapter has shown that there are no CSR blueprints. The most appropriate strategies depend on the country of operation, management commitment, industry, economy, and workforce, but one thing is clear, CSR appears to have become an integral part of how corporations do business today.

In the following section the research design is presented followed by a summary of the two industries being studied. The final sections consist of the two case studies, benefits and limitations, findings and a conclusion. The case studies will link some of the issues and explanations described in the literature review section. In particular the case studies will look at lessons leamed, challenges and some initiatives undertaken under the corporate social responsibility umbrella.

A final comment, according to Caroll (1999) CSR has a "bright future becouse at its core it addresses and captures the most important concerns of the public regarding business and society relationships". 


\section{RESEARCH DESIGN}

\subsection{Methodology}

The objective of the research was to contribute to the understanding of CSR in global companies, by obtaining information from two different companies and producing two case studies. Case studies have been used successfully by Wheeler et al (2002), Cragg and Greenbaum (2002), Kapelus (2002), MacDonald (1994) and others to contribute to the CSR literature. Case studies are increasingly being used as a research tool and have been a common research strategy in psychology, sociology, political science, business, social work, and planning (Yin, 1994). This research was an attempt to provide insight into the challenges, practices and lessons learned that organizations face while implementing and improving CSR.

The case study methodology is a preferred approach to examine contemporary events; Yin (1994) argues that the case study's unique strength is its ability to deal with a full variety of evidence: documents, artifacts, interviews, and observations. The reason for selecting case studies as the methodology was to obtain descriptive type of information. The researcher wanted to understand the lessons learned, challenges and future areas of CSR and case studies is one of the best methods for obtaining comprehensive-type of data. As mentioned in the methodology section of this thesis case studies have been used in the past by a number of authors, including the government of Canada, to understand what companies are doing in CSR. In addition case studies support numerous research tools and are useful ways to obtain information on the historical background, procedures, processes, and activities of companies. 
The reasons for selecting the industries studied are two fold; firstly both industries have received a lot of media attention due to past irresponsible corporate and operational behaviour, therefore making it probable that companies in these industries have internal CSR strategies. Secondly, the researcher has worked in both industries and brings some personal experience to the sectors studied.

The process of selecting the companies studied was more complicated since it was difficult to obtain commitment from management. It is unclear why this could not be obtained easily, but it could be because corporate social responsibility is a sensitive issue since it deals directly with a company's reputation. In addition, it is believed by the researcher that although corporate social responsibility has been endorsed by large multinationals, it is still a recent phenomenon and management is still uncertain about stakeholder expectations. The selection process of the two companies consisted of first identifying companies that were working in the industries studied, that were involved in CSR and that the research could be undertaken from a logistical point of view. Six companies were identified initially and letters were written to explain the research process. Following this, the researcher narrowed down the selection to two companies and called the people responsible for corporate social responsibility. The reason for narrowing down the selection to two firms was that the researcher had some personal and work contacts in these two companies and believed that it would be easier to obtain an agreement to conduct the research.

The first phase of the study consisted of undertaking a literature review on CSR in general and in particular on CSR actions and experiences implemented by companies working in the international arena. This was followed by the development of the survey instrument and identification and selection of two companies working in international business in two different industrial sectors. Thirdly, the researcher proceeded with secondary data 
gathering using corporate documents, policy statements, annual reports, written codes of conduct and company websites. Fourthly, the researcher modified the survey instrument, based on the secondary data collected and the researcher proceeded with the collection of primary data by holding interviews with senior staff and/or with the person responsible for the CSR department (or equivalent). Questions consisted of examining the issues raised in the literature review and exploring the types of CSR initiatives implemented. The final phase consisted of writing the case studies, summarizing the findings of the case studies and comparing these findings. See Appendix 1 for a graphic illustration of the research study process.

Table 1 - Study Methodology by Phases

\begin{tabular}{|l|l|}
\hline Phase 1 & \multicolumn{1}{|c|}{ Study Methodology } \\
\hline Phase 2 & Completion of literature review \\
\hline Phase 3 & Development of survey instrument \\
\hline Phase 4 & Selection of two companies to participate in case study \\
\hline Phase 5 & Secondary data gathering \\
\hline Phase 6 & $\begin{array}{l}\text { Modification and adaptation of survey instrument and } \\
\text { collection of primary data by conducting interviews }\end{array}$ \\
\hline
\end{tabular}

The case studies focused on several issues identified in the literature review, including:

- Identification of CSR strategies (including codes of conduct) and activities.

- Lessons learned.

- Determining impacts of CSR implementation.

- Accountability and reporting issues.

- CSR policies and guidelines.

- Top management involvement.

- Challenges. 
As mentioned in the beginning of this paper, it is important to understand that the purpose of the case studies was not to evaluate, judge nor criticize the companies examined but rather it was an attempt to understand some of the challenges, lessons learned, activities and general CSR implementation experiences. This thesis was an effort to document and compare two industries working in the international market place.

The cases are presented first by providing a company background. This is followed by a description of their corporate social responsibility and a description of their policy, strategy or equivalent. The following section describes some of the activities undertaken by the companies reflecting their corporate social responsibility policy. Other sections include challenges, future considerations, impacts of being socially and environmentally responsible, and lessons learned. The information gathered from primary and secondary sources was compiled and presented together in each different section as a narrative form. Therefore, the information gathered from interviewees, company reports, and the internet is not separated in each section but has all been pulled together and presented in this fashion to facilitate the reading process. The cases describe in detail the findings of the interview sessions which relate directly to the research objectives. A brief summary is provided at the end of each case study and a comparative description is presented in the findings section of this report.

\subsection{Sample}

Two case studies were developed focusing on the issues mentioned in the literature review. The companies interviewed were from different industrial sectors; one from a primary resource company and the other a producer of outdoor products. The researcher 
interviewed two representatives from MEC in Canada and three people from Company $X$; one person from Canada and two from Country $\mathrm{A}$. The reason for using this methodology was to gather information on two likely different approaches to CSR; whether a direct investment through the establishment of a subsidiary in the local country or the establishment of a partnership/supplier joint venture relationship.

In addition to the companies studied, the researcher also interviewed one non-profit organization working with $\mathrm{MEC}$ and an NGO working with company $\mathrm{X}$ in country $\mathrm{A}$. One representative was selected from each organization and one meeting was held to discuss and confirm some of the information that had been obtained from documents, the internet and from the interview sessions with the firms. The results of these meetings have been integrated in the case studies.

\subsection{Data Collection}

The methods used to gather data were two-fold; secondary data through examination of corporate documents and primary data through formal individual interviews. The primary data was collected using face to face interviews, telephone and e-mail. A number of interview sessions were held with the representatives of the companies and the NGOs.

The secondary and primary data gathered for each individual company have been presented in a case study format and findings have been compared. Common trends, differences, challenges, lessons leamed, policies and values for each company have been documented in this thesis. 


\subsection{Instrumon}

The instrument used to gather information was a questionnaire (see Appendix 2). Two questionnaires were prepared, one for the companies and another shorter one for the NGOs. Some of the questions outlined in the proposal were modified after gathering the secondary data. This was done to reflect better the information gathered from documents and the internet. 


\section{THE GARMENT AND FOOTWEAR INDUSTRY}

The garment sector has had a history of labour disputes for almost a century. There have been struggles to protest low pay, long working hours, lack of benefits, and unsafe working conditions since June 3, 1900, when the garment workers from the International Ladies Garment Workers' Union (ILGWU) first started to protest. The first garment strike in the US took place in 1909 and was organized by the ILGWU. In 1911, as a result of a fire that killed 146 garment workers in New York City, the government established a regulatory control over the industry. This fire shook the public and changed the way they looked at the industry.

In 1938, the US government approved the Fair Labour Standard Act (still operational today), which guaranteed a minimum hourly wage and overtime requirements. In the $1960^{\prime} \mathrm{s}$ and $80^{\circ} \mathrm{s}$, globalization first started to appear in the garment industry due to strict regulations regarding unions, wages and benefits in the US and US companies started to move factories to developing countries to produce their products. Due to increased access to information, some developing countries also started to demand similar conditions and regulations as in the US. As a result, during the 1980's many manufacturers and retailers began outsourcing their production to countries in Central America and Asia. This allowed Western companies to start concentrating on their core competencies. In order to encourage foreign investment developing countries developed export free zones allowing manufacturing companies to produce their products in developing countries and thus benefiting from low wages in a regulatory-free environment. 
In the $1990^{\prime}$ s, due to increased pressure from foreign subcontractors and increased regulations, some factories started to reappear once again in North America. However, the labour problems were also prevalent in North America. In 1995, the US government asked large manufacturers and retailers to support cleaning up the "sweatshops". This resulted in a "Statement of Principles", which states that retailers will agree to ask their suppliers to comply with all hour and wage laws that apply to them. The US government got more involved and established tripartite discussions between the government, unions and the industry (Now and Then Time Line; TV News MSNBC- Internet).

In the UK, public pressure in the garment industry resulted in the September 1999 global sweatshop campaign which "urges retailers to ensure that workers employed by their" subcontractors do not suffer through low wages and poor conditions. Instead of moving production elsewhere when failings are revealed, we ask them to draw ap codes of conduct and to have them independently monitored. In addition, we call for;

- all leading retailers to report anmally on their social auditing,

- a change in the low to make country-of-origin labeling compulsory

- steps towards an ethical trade "kitemark" indicating standards of poy and conditions" (IIED 2000; p.23).

In the $90^{\circ}$ s the garment and footwear industry started to receive a lot of publicity due to celebrities getting involved in the endorsement of labels and brands and also celebrities involved in the fight against the practice of using sweatshops (Now and Then Time Line; TV News MSNBC-Intemet). As a result of the publicity, in 1995 Gap agreed and became the first US apparel company to allow independent monitors to evaluate their factories in Central America. 
Some of the social and environmental problems confronting these industries stem from the way the industries are organized, variations in production and buying patterns, variation in the labour market, and fierce global competition. Other social problems are attached to work done at home and subcontracting. In general, the wage paid to home workers is less than to factory workers. In addition, the working conditions are usually worse and the production might not be as effective since there are distractions at home. These home workers also generally tend to be seasonal workers without protection or contracts (ILO, 1969).

In many developing countries such as Morocco, Haiti, Honduras, Mexico and Bangladesh, the majority of workers in the garment sector are women, although culturally it might not be acceptable for women to work. This is because women tend to accept lower salaries and will accept worse working conditions.

As mentioned above, there has been a tendency for American and European companies to move or outsource their production abroad searching easier regulations and cheaper labour. In many countries, the garment and footwear industry is almost entirely based on subcontracting with European and North American firms. Western companies supply local companies with all the requirements and materials needed to produce, and the local companies provide cheap labour and assembled products. These products are later exported and sold in retail businesses abroad (Cairoli, 1999).

According to the US retailers in the apparel industry there are several options to outsource production to foreign partners. High quality retailers focusing on designer goods tend to outsource their production to factories located in Italy, France, the UK and Japan. Specialty chains focusing on labeled goods will outsource in Taiwan, South Korea, 
Singapore, Hong Kong, Malaysia, Thailand, Mexico, Brazil, Egypt, Turkey, India, China, Philippines, and Indonesia. Retailers selling brands to mass markets will concentrate more on lower costs and medium quality and will outsource from some of the above mentioned countries and also from Central America, the Caribbean, Colombia, Chile, Eastern Europe, Kenya, Zimbabwe, Mauritius, Macao, Pakistan, Sri Lanka, Bangladesh, China, Tunisia, Morocco, UAE, and Oman. Finally, discount stores focusing mostly on lower costs and selling large volumes will outsource from some of the above and from Peru, Bolivia, El Salvador Nicaragua, Vietnam, Russia, Lesotho, Madagascar, North Korea, Myanmar, Cambodia, Laos, Maldives, Fiji, Cyprus, Qatar and Bahrain. Some Western retailers buy from all these countries (IIED, 2000).

The industry for subcontractors is highly competitive since foreign companies move from one company to another looking for lower costs. Therefore, workers are at high risk and work is insecure. The workers feel this impact since they get hired and then laid off a few months later, to be rehired once again. The majority of factories in developing countries completely disregard labour regulations and the workers have little recourse against these companies for fear of getting laid off. This does not only affect the workers in developing countries, but also those from North America who are mostly immigrant women (Cairoli, 1999).

In a typical factory the working situation is often harsh. There are few breaks, sometimes lack of ventilation and inadequate lighting, few exits, dirty washrooms, lack of potable water, cramped spaces, lack of working agreements, lack of benefits, physical and verbal abuse, lack of job protection, long working hours, child labour, dismissal of pregnant women, and lack of child care facilities. In many countries the labour law stipulates that child care must be provided if the company employs a certain number of women. 
(Petersen, 1994). According to Frynas (2003) the appeals received by the Cleans Clothes Campaign (CCC) in order of importance are lack of trade unions and collective bargaining, unjust dismissal, low wages, inadequate healthy and safe working environment, long working hours, workplace discrimination, and lack of leisure and rest during work.

In the last decade, factories in developing countries have been receiving pressure from Western companies to "clean-up" their factories. For example, in the mid 90's, Century Textiles from India, a leading textile manufacturer, was encouraged by German buyers to phase out toxic dyes. As a result, the company introduced new dyes and obtained the independent Eco-Tex Standard Certification (IIED, 2000).

Unfortunately, increased pressure for environmental and social compliance from developed countries (stems from media attention and civil rights groups) has had some negative impacts in some developing countries. Some developing countries do not have the technical or financial capabilities to comply with some of the environmental standards being imposed by some Western companies and countries. This, of course, leads to marginalization since these countries are not in a position to comply with some regulations (Who benefits? - Internet). However, it is expected that gradually some countries will be able to comply with Western standards. Ideally, compliance should be set to reflect local realities and should be adapted to each individual country or region, allowing countries to gradually meet stricter standards.

Outsourcing from low cost developing countries has had some benefits for companies in the West, including mass production and low costs. However, there have also been negative impacts such as lack of innovation, high turn around times, low quality and bad 
publicity. For example, Nike in the 90 's received intense criticism regarding their social and environmental performance from civil rights groups and social justice campaigns. Nike was accused of exploiting child labour and condoning human rights (IIED, 2000).

Poor environmental and social conditions in the supply chain have huge impacts on the public perception of the industry and this impacts individual company image and brand value. Companies have recognized that this is a problem and have been cleaning up their image. As discussed above the challenges faced by the industry are child labour, dismissal of pregnant women, working conditions (low safety standards, lack of ventilation, lack of breaks, etc.), low wages, water pollution, solid waste problems, labour standards, excessive water consumption, and reduction of toxic chemicals particularly in the dyeing process (IED, 2000 and "Who Benefits?" - Internet Research).

Finally, the garment and footwear industries in the West have received pressure to improve the environmental and social performance of their outsourcing partners. The focus from pressure groups is specifically aimed at improving the labour rights for workers (Frynas, 2003). There is strong market pressure for companies to comply with labour standards, supplier code of conducts and sustainable practices which incorporate social and environmental factors into all key purchasing decisions. 


\section{CASE STUDY\#1 - MEC}

\subsection{Introduction}

The cases have been selected specifically because they are each very different, in regards to their industry, operations and international approach. The first case is a retail business based in Canada but partnering internationally and domestically with suppliers and contractors. This company outsources the supply chain to international suppliers and builds partnerships to manufacture outdoor products that are sold in Canada. The second case study is a company, also from Canada, but involved in the oil and gas industry with offices in several countries throughout the world.

It is important to mention, that each company calls their corporate social responsibility department and or policy differently. For example, at Mountain Equipment Co-op (MEC) corporate social responsibility is headed by the Social and Environmental Group and in Company $\mathrm{X}$ by the Corporate Responsibility and International Relations Group.

The first case study is a company that sells outdoor products through their retail stores located in Canada. It is a Canadian company highly known for its corporate citizenship approach and involvement in the protection of societies and the environment. It is a retail business operating throughout Canada but the supply chain component is outsourced to partners in Canada and other countries. In 2003 a total of 35 factories in 9 countries had a partnership agreement with MEC to produce MEC products. The distribution of the factories are 17 factories in Canada, 1 in Japan, 1 in New Zealand, 1 in Portugal, 1 in India, 2 in Taiwan, 2 in Thailand, 3 in Vietnam, and 7 in China. 


\subsection{Company Background}

The company researched is Mountain Equipment Co-op (MEC). MEC is Canada's largest supplier of outdoor equipment and services industry; it is a retailer providing goods directly to suppliers on a membership basis.

The idea of MEC was first conceived by a group of Canadian mountaineer friends in 1971. After some discussions regarding the lack of outdoor equipment in Canada, a decision was made to provide equipment for mountaineering, rock climbing, ski mountaineering and touring, hiking, paddling and bicycle touring. MEC was originally created as a mail order company which gradually grew into a large retail business. The first store was opened in Vancouver and grew from a closet to an aircraft hangar, it consisted of a humble second floor office on Hastings Street. The head office has grown due to good management vision focusing on member relationships and MEC is now located in a large building on West Broadway. MEC has retail stores throughout Canada and out-sources, through partnership agreements, the production of MEC products.

Today, Mountain Equipment Co-op is a member-owned business which continues providing products and services oriented to recreational activities. The core purpose of the company since 1971 has been to support people in achieving the benefit of self-propelied, wilderness-oriented recreation. The goal of MEC is "to reduce the ecological impact of 
maning our business while increasing the positive impact we hove on people and communities".

\subsection{Corporate Social Responsibility at MEC}

Corporate social responsibility at MEC is governed by MEC's Guiding Statements and Sustainability Policy. The company believes that the economy, the environment and society are interdependent and MEC has a responsibility to make the world more sustainable and thus they encourage and support members to lead healthy lives. MEC promotes wilderness conservation and the responsible use of the outdoors. They endeavor to improve the social and environmental impacts of their products and services and work with communities to support social and environmental goals (this will be demonstrated in another section through some of the activities and initiatives supported by MEC under the social and environmental group). The sustainability policy is presented in section 6.4.

The company has integrated sustainability into a business model and has progressed from guiding statements to integrating sustainability into their products, i.e. it has followed the historical progress mentioned in the literature review of issuing policy statements to taking actions that reflect their sustainability policy. Therefore the company is not merely talking about being sustainable but it has taken specific actions to link its CSR activities with the company's policy statement or guiding statements. The business model used by $\mathrm{MEC}$ progresses from an easier to harder approach and is described in the following page; 


$\begin{array}{lllll}\text { Guiding } & \text { Strategic } & \text { Business } & \text { Cycles and } & \text { Accountability } \\ \text { Statement } & \text { Planning } & \text { Operations } & \text { Structures } & \text { Sustainability }\end{array}$

Easier

Harder

Figure 1 - MEC Business Model

The business model evolves from making statements about the business being sustainable to making it happen by taking specific action to match the strategy. Guiding statements consist of developing policy to reflect social and environmental issues and including them into the company's core values, such as the development of MEC's Community Involvement Policy. Strategic planning involves incorporating corporate responsibility into business planning, cycles and operations and includes, amongst other things, working and partnering with stakeholders that match the company's core values. Accountability structures include linking sustainability into the employee's job description such as using performance to evaluate the employee's sustainability actions. It is about MEC being held accountable and being able to measure and monitor progress to meet MEC's commitments. It is also about reporting on their social and environmental performance publicly and engaging their stakeholders in meaningful dialogue.

Sustainability actions include recycling paper and controlling energy use. Finally, embedding sustainability consists of mainstreaming corporate social responsibility into all operations. It consists of taking strategic action for being responsible. It can include 
supply chain activities which reduce the toxicity of products and using natural fibers to reduce waste

MEC still actively operationalizes all the different levels of their business model at different stages of the life cycle. The model is not static; it is a dynamic model that can move from one level to another in different departments.

As mentioned previously, MEC out-sources the manufacture of its products to partner companies. To ensure compliance with MEC values, core purpose, mission, vision and commitment to sustainability, the company produced a sourcing policy and a supplier code of conduct which will be explained below.

The guiding principles of the sourcing policy is to ensure that the supplier code of conduct is reviewed annually and conforms to the international labour organization's (ILO) core labour standards, to ensure that suppliers are aware that MEC expects them to comply with their code of conduct, to use internal and external auditors to ensure code of conduct compliance, and to assist suppliers that have not complied to improving their work practices. A very important aspect of the sourcing policy is reporting and evaluation. MEC's sourcing performance is monitored and reported on an amual basis to the Board of Directors, members and the public. 
68

MEC's supplier code of conduct has been developed to ensure a safe workplace for partner employees. The different aspects of the code of conduct are 1) child labour-MEC suppliers do not hire children under the age of $15 ; 2$ ) forced labour - MEC suppliers do no use forced or illegal labour; 3) disciplinary practices/coercion - MEC suppliers treat employees with respect and dignity; 4) freedom of association - MEC suppliers recognize that employees have the right to join trade unions; 5) wages and benefits - MEC suppliers ensure that they meet the country's legal requirements for wages and benefits; 6) working hours - MEC suppliers ensure that working hours do not exceed 60 hours per week; 7) discrimination - MEC will not work with suppliers who discriminate on the basis of race, gender, political or religious beliefs, social, ethnic or national origin, marital status, age, union affiliation, sexual orientation, or disability; 8) health and safety - MEC suppliers will provide workers with a safe and healthy working environment; 9) environmental commitment - MEC suppliers will implement and maintain systems to minimize the negative impact of manufacturing and packaging on the environment; and finally 10) compliance and implementation - suppliers are subject to monitoring and auditing to ensure MEC compliance.

Corporate social responsibility at $\mathrm{MEC}$ is put into action by the social and environmental group. The group is headed by a social and environmental manager who strongly believes that "sustainability must become part of what we do, the core purpose of MEC is not to sell outdoor gear but to help people experience wilderness". 


\subsection{MEC's Sustainabillity Policy}

The sustainability policy was developed to "ensure we're walking our talk and ensure that we frame what we do as a business and/or as employees through sustainability items"(Denise Tachereau: Interview session). It was developed as a framework and to provide direction to MEC on how to be socially and environmentally responsible. In 1999, after two years of consultation with MEC staff, the company developed a formal sustainability policy to ensure their leadership role. A very important aspect of the sustainability policy is the recognition in this policy that anything done by MEC has an impact on the planet, the communities, the economy, etc. The policy incorporates 4 areas or 4 pillars of sustainability which include business operations, product sustainability, sustainable consumption, and community involvement.

The business operations focus on sustainable operations such as waste and recycling, energy efficiency in stores, water improvements, environmentally friendly walls, provision of a safe workplace where employees are treated fairly and with respect, and other activities which relate directly to the business operations. MEC wants to lead by example in particular in regards to energy, water and material use. Product sustainability relates to product specific action which includes the materials used in their products and the impact of these products on the environment and society, human rights considerations in the supply chain, supply chain labour rights, dignity and quality of life for the employees, respect for civil and human rights, and making products long lasting and durable. In other 
words, it includes all the different areas involved in production. The purpose is to minimize or eliminate negative impacts and enhance positive impacts of their products and services.

Sustainable consumption takes into account consumerism and member needs by having available swaps between members and providing members with gear at a rental price rather than selling gear only. Sustainable consumption is about understanding some of the needs of consumers regarding selling vs. renting, which indirectly seems to contradict the sales of products. However it builds a relationship and customer loyalty since it gives the impression that MEC understands the needs of consumers. It is about MEC understanding the needs of their clients and providing them with alternatives to contribute to an improved and higher quality of life.

Finally, community involvement is $\mathrm{MEC}^{\prime}$ s way of involving the communities and contributing part of its revenue to environmental initiatives. In line with the company's core business, which is to provide outdoor equipment, MEC provides $0.4 \%$ of their previous year's sales to an environment fund to support communities, environmental groups, groups that support outdoor activities, and community group displays. The community investment program at MEC is a classic example of a company that provides benefits to communities and links them directly to the core business, beliefs and strategic priorities. "MEC's main focus is to protect and build a sustainable environment, I 
strongly believe that companies should focus on the core competencies for community imolvement" (Denise Tachereau: Interview session).

\subsection{Corporate Social Responsibility in Action}

As mentioned above, MEC has moved forward from stating policy to applying policy and developing programs, activities, and initiatives that reflect this policy. Some of the activities undertaken by MEC are provided below, but this is not an exhaustive list. They are presented here merely as examples of CSR policy implementation.

1. The retail stores at MEC employ environmentally friendly building features such as higher efficiency heating, ventilation, air conditioning systems, low-consumption water fixtures, and reduction of energy use in heating and cooling systems, maximization of natural light, and an increase in the green space of their stores.

2. MEC has incorporated the four $\mathbb{R}^{\prime} s$ - reduce, reuse, recycle and reclaim in design and construction of their stores.

3. MEC has implemented the national C2000 Green Building Standard ("green buildings") which includes the use of half the energy consumption of a conventional building. Creating a Green Program to "cleon up our own backyard" (Denise Tachereau : Interview session).

4. The company has set up a heating and ventilation system that contains no ozonedepleting substances. 
5. Action has been undertaken to ensure that international partners meet the core values of MEC. This is especially true and relevant for partners who manufacture MEC products. The company uses third party auditors who evaluate partners through the use of a questionnaire. In addition an inspection of the supplier's code of conduct and a physical audit is undertaken. MEC has developed different tools to support its ethical sourcing efforts; supplier code of conduct, sourcing policy, STEP auditing and the use of $3^{\text {rd }}$ party independent audits.

6. MEC has incorporated sustainability in job descriptions and provided incentives for corporate responsibility performance. Things such as organic organizing and measuring recycling efforts are activities which are evaluated through the use of a value questionnaire.

7. A full-time Social and Environmental Responsibility Manager and a Co-op and Community Development Coordinator to oversee MEC-wide efforts have been hired and are working actively in the program to provide improvements to the initiatives that reflect the sustainability policy.

8. Implementation of an Old Growth Free Policy. The objective of this policy is to phase out all products that contain old growth pulp. The company also plans to reduce overall fiber consumption to $30 \%$ by 2005 .

9. Development of a Community Involvement Policy. This policy provides considerations to guide community involvement activities by defining strategic themes such as wilderness conservation and the benefits of self-propelled 
wilderness recreation. As mentioned previously, the community involvement policy directly matches the core business of MEC.

10. Creation of a Social and Environmental Responsibility Network. This consists of company representatives from every functional department, a full-time Environment Fund Coordinator, as well as part-time Social and Environmental Responsibility representatives from every store.

11. Partnerships between individual retail stores and local business community groups have been instituted to engage in mutually developed projects such as local river clean-ups, seasonal food and clothing drives, and alternative transportation awareness campaigns.

12. Development of an MEC Environment Fund: The objectives of the MEC Environment fund are to protect outdoor environment areas of significant recreation or wilderness value to $\mathrm{MEC}$ members, where appropriate to facilitate public access and recreation use, and to educate MEC members and the general public in wilderness issues and to build on their awareness, concern, and support for protection of the natural environment. Since 1987 the company has contributed over $\$ 4$ million to Canadian-based environmental conservation and wildemess protection projects, research and education. In 2002, MEC granted Cdn $\$ 550,000$ to the enviromment fund.

13. MEC has made contributions to the Jedediah Island Land Acquisition aimed at protecting the island. The island is marked by old-growth forest, a large meadow, sandy coves and rocky outcrops. MEC has provided a grant to a graduate student 
to research the impacts of logging and landscape change on dragonfly populations along the Main River in Newfoundland. The research was critical to understanding the dragonfly movements between disturbed and undisturbed areas aimed at conserving functional ecosystems. In addition, MEC contributed to funding the research of a student to study the behaviour and habitat of western small-footed bats found in parts of Alberta, British Columbia and Saskatchewan. The support of this research will contribute to understanding the impact of major flooding events and support the development of better management strategies.

MEC has contributed to Community Based Organization and Environmental Groups. In 2002 MEC contributed Cdn $\$ 650,000$ in grants and contributions to the community. Grants are allocated to support environmental education and advocacy projects, land acquisitions, research and studentships, and access projects. In 2002 MEC funded a land acquisition on Davis Creek in Quebec to protect the Mount Sutton Corridor with the Nature Conservancy of Canada, the Boreal Rendezvous - a Canadian Parks and wilderness society canoe expedition, and supported the establishment of Mealy Mountains National Park in Labrador through the Canadian Nature Federation. Other smaller initiatives undertaken through MEC stores have included funding Toronto's Community Bicycling Network, Winnipeg's Save the Seine, the Alberta Wilderness Association, and a Baffin Island Study of Arctic Marine Cod. 
In $2002 \mathrm{MEC}$ provided support to five expeditions by providing small grants to help equip member expeditions. The two principal initiatives were the strengthening of the Canadian Avalanche Association membership by becoming a presenting sponsor with a donation of $\$ 50,000$ and partnering with SEVA Canada to celebrate the International year of Mountains to support the multimedia shows Himalayan Visions and Tibetan Voices.

Finally, as mentioned above MEC has a supplier auditing program to monitor compliance regarding their supplier code of conduct. This is done through the Supply Team Evaluation Process (STEP) audit. MEC produces reports for the public indicating the activities undertaken by MEC to ensure supplier compliance with the Supplier Code of Conduct.

MEC has developed a questionnaire to identify if there is compliance with their supplier code of conduct. The issues that are of concern for MEC include key labour issues such as health and safety, security, wages, working hours, and others. Specifically post fire emergency procedures and plans, trained certified first aid attendants, inspection of exits, accessibility and maintenance of first aid kits, maintenance of accident logs, availability of personal protection equipment such as gloves for cutters, implementation of recycling programs, detailed breakdown of compensation on payroll records, provision of employment agreements, proper payment for overtime work, amongst others. 
The audits are undertaken by intemal supply team evaluators and a third party intemational NGO that underakes independent audits of factories. The auditors conduct independent interviews of the workers and identify issues and action plans which are later used as a follow-up and as a tool to measure improvements and/or deficiencies. The partners are assisted to meet MEC standards and given a chance to improve their code of conduct. According to the social and environmental manager, if, after a certain time, there are still substantial non-compliance reports, MEC will stop using these suppliers. Third party certification is one of the broad categories discussed in the literature review and classified by Gereffi, Johnson, and Sasser (2001).

\subsubsection{Community-Based Organizations (CBOs) and Environmental Groups}

$\mathrm{MEC}$ has a number of community partners. $0.4 \%$ of their yearly sales are donated to these kinds of institutions. MEC believes that by nurturing meaningful partnerships with organizations they can help to protect and enhance the places where they work and play, and thus contribute to their core values and sustainability strategy. Some of their partners include:

Canadian Co-operative Association (CCA)

MEC is a member of the Canadian Cooperative Association. Through their association with the CCA, MEC is looking for ways to improve the co-operative sector in Canada. 
Canadian Avalanche Association

The MEC is a supporter of the Canadian Avalanche Association, a non-profit society created in 1981 to bring together professionals to provide avalanche education, and promote industry standards to enhance avalanche safety for backcountry aficionados across Canada.

Outdoor Industry Conservation Alliance

MEC is a member of the Outdoor Industry Conservation Alliance, an organization which represents approximately 62 outdoor businesses whose collective contributions support the efforts of citizen-action groups aiming at protecting wilderness areas for the benefit of outdoor enthusiasts.

Canadian Business for Social Responsibility

MEC is a member of the Canadian Business for Social Responsibility mentioned in the literature section of this thesis.

Business for Social Responsibility

MEC is also a member of the Business for Social Responsibility headquartered in Seattle. This organization provides tools to implement socially and environmentally responsible polices and practices in business. 


\subsection{Challenges of Moving Forward}

The following section provides insight into some of the challenges faced by the team in the social and environmental group to move forward the corporate social responsibility agenda.

The Social and Environmental Responsibility Manager spends 80\% of her time changing minds at MEC, $10 \%$ drafting and changing policy, and $10 \%$ undertaking administrative duties. This shows that although substantial progress has been made, as mentioned in the previous section, internal lobbying and understanding of the importance of CSR is still not well understood or assimilated internally, even in a corporation such as MEC. For example, the social and environmental manager mentioned that it is crucial for her department to identify corporate champions who will be conscious of environmental and social issues and implement changes in their individual departments. In addition, she mentioned that she still gets asked questions about what is the responsibility of the social and environmental group.

Another challenge mentioned by the interviewees is educating and creating consumer awareness regarding environmentally friendly products and sustainable approaches to operations. There is still a lack of awareness regarding sustainability and the responsibility of companies and also consumers. There is also a lack of awareness regarding the history 
of some products and whether the products are made with sustainable materials. This is a clear indication that marketing needs to be improved in this area.

In addition, related to sustainable and environmentally friendly products is the difficulty of finding sustainable materials and designs that appeal to members. Further research is required to meet the fashion needs of consumers. Also, improved methods and operation approaches towards decreasing the environmental footprint of their products and mitigating impacts are required.

Another challenge is the method or process used to audit partners. An improved method of auditing and/or approaching partners is preferred.

As seen in the literature review, performance is difficult to measure, MEC also recognizes this fact and it is a challenge for the company. This is a key issue which customers are increasingly demanding. $\mathrm{MEC}$ did not have further information to provide regarding performance measurement, other than a brief comment which will be discussed later in this paper.

Setting priorities is also very important due to limited resources. MEC understands that in order to make a positive change it is imperative to identify the areas where MEC has influence and the areas where positive changes and differences will be made in the 
corporation. MEC concentrates in outdoor products and services and the environment is their main focus for their CSR initiatives.

Some of the grassroots organizations which are interested in working with $\mathrm{MEC}$ are very small and do not have the infrastructure to undertake projects or programs. This is a challenge since there are many requests for funding, but chances of success with smaller groups are more limited. An improved method is required to reach these grassroots organizations to make them more effective and efficient.

Finally, and directly linked to the discussions mentioned above, is the challenge of identifying methods, best approaches and lessons learned on how to lobby internally to reach and target the Vice Presidents and management at MEC in order to achieve effective and positive change

\subsection{Future Considerations at MEC}

The future considerations for MEC all revolve around making improvements to match the sustainability strategy. The future considerations mentioned in this section consist of areas mentioned by the social and environmental group and do not include other departments at MEC. 
The main areas for fusure consideration include improvement of the programs and activities to better match the sustainability strategy, increase awareness and further strategic engagement with the communities at the grassroots level. There is still a need to improve consumer education and information. The social and environmental manager mentioned that there is a need to inform the public about the value added of MEC products. That a jacket, for example, has been made by a company that has been audited using environmental and social standards. Innovations and research are required to develop improved sustainable materials. The organization also needs better mechanisms for measuring social and environmental performance and increased accountability of reporting measures to show "how much" the company is controlling or measuring energy efficiency.

$\mathrm{MEC}$ believes that consumers want to see numbers reflecting the implementation of the sustainability policy. The public also appreciate the adoption of a "practice what you preach" approach. The creation of the new Sustainability Policy to incorporate and drive new waste, energy, and material use reduction programs, the provision of funding to Community Based Organizations and Environmental Groups that is not project based but rather core funding, revisions of the MEC endowment fund and finally increased levels of member and staff involvement in MEC community programs are some of the areas that need to be improved and considered further for the future. 


\subsection{Impacts of Being Socially and Environmentally Responsible}

MEC has integrated CSR into all facets of its operations and they believe that CSR contributes to the overall performance of MEC. The social and environmental manager stated that "MEC believes that being socially and environmentally responsible increases membership loyalty, increases employee satisfaction and loyalty, and improves employee retention". However, MEC could not provide specific quantitative data demonstrating financial benefits.

"In addition, MEC is recognized in Canada as a sustainable enterprise, and customers expect MEC to be socially and environmentally responsible. It is infused in our mandate and mission statement. The MEC brand is very important to the value of the company and it is extremely important not to harm this image. It has been embedded in who we are and how the staff view themselves. It goes well beyond reputation management" (Denise Tachereau: Interview session).

MEC believes that being socially and environmentally responsible leads to energy efficiency and conservation of materials and resources. Since MEC is involved in the outdoor business it is in their business interest to conserve the environment and minimize the ecological footprint to allow members to use their products and services and continue experiencing the outdoors. This impact is directly linked to the company's purpose of allowing members to experience the wilderness. 
The MEC social and environmental group implements corporate social responsibility initiatives throughout the communities. They focus specifically on environmental issues and support NGOs and charity organizations that have a focus on MEC's core competencies (according to MEC there is more value and sustainability in focusing on MEC's core competencies). CR initiatives implemented by MEC have had an impact on the communities. For example, the NSMBA (North Shore Mountain Bike Association) claims that the public has benefited since MEC has provided support to build bike trails and environmentally sensitive signage.

As mentioned in the previous section, an improved and more efficient method and mechanism for measuring social and environmental performance is one of the areas for future consideration and improvement at MEC. As seen in the literature review there are difficulties in determining whether being socially responsible leads to some type of improved performance. Measurement of performance is difficult since CSR deals mostly with qualitative items, however there are some areas that can be quantified and although not exhaustive the following are some of the performance indicators supplied by MEC to measure performance; number of major deficiencies, number of factories and suppliers rejected through auditors, number of factories where MEC continues to purchase and finally the number of minor deficiencies both at MEC and suppliers e.g. missing first aid kits, fire extinguishers, and others. 


\subsection{Lessons Learned}

Lessons learned are increasingly being used by corporations to identify deficiencies and benefits of policies and programs. MEC has also been developing their lessons learned and are provided below.

An important lesson learned for MEC is identifying areas of change and putting the limited resources to achieve that change. According to $\mathrm{MEC}$, the implementation of this change can only be done through internal champions who can assist the CSR program and are truly committed to the idea, champions that have influence to effect change. One very important step that must be taken prior to identifying the champion is identifying the program where change is required. It could be human resources, purchasing, or another department, and within that department a champion should be identified. For example, if CSR accountability needs to be written into job descriptions and job evaluations, then the person responsible for writing these job evaluations needs to be the champion and needs to be targeted by the CSR team. This is what is called embedded sustainability which is also linked to performance management. Another requirement is having an innovative and progressive board to influence policy and CSR direction and commitment by all employees.

Another lesson learned is giving accountability to the department or program for CSR commitment rather than to the Social and Environmental Group. This way there is more 
focus and more accountability if results are not achieved. The Social and Environmental Group should not be implementers of activities but rather act more as advisors and move to areas where they are needed or have been identified as a priority. It should not be a "one person show".

Communication and education are also very important. The staff at MEC need to be continuously educated about CSR and the activities that are being done in the corporation. It is surprising, but according to MEC, a lot of people still do not know what the CSR person does, therefore continuous internal education and communication is required to achieve buy-in and to identify champions and areas and individuals that require more assistance. An important communication tool mentioned by MEC is story telling and showing good and bad examples of initiatives and programs.

Auditing partners, using a third party, has proven to be key to changing the rules of the game for retailers to help them understand what is happening in the supply chain and support them in changing practices.

Another important lesson learned for MEC consists of labour issues and human rights regarding their international partners. MEC sourcing policy was written in 1997 but it was not linked to other international human rights or labour standards such as those from the International labour Organization (LO). This caused some problems initially, but the policy was later rewritten to take into account international standards and protocols since 
the partners were mostly from other countries. The new policy included international standards regarding workers rights, supplier codes of conduct, and referenced the United Nations Universal Declaration of Human Rights. Another important point that obtained buy-in from staff was that the policy was reviewed and shared by staff.

A substantial amount of time is spent lobbying internally. This is required to obtain creative ideas and further commitment to social responsibility.

Stakeholders such as CBOs have understood the value of true partnership by dialoguing and discussing constructive ideas. This has been achieved through dialogue and financial and technical assistance. Communication and feedback with these groups are very important. "Building trust and an honest and open relationship are key to achieving a true working relationship" (Denise Tachereau: Interview session).

Finally, another lesson learned is that community investment needs to reflect the core business of the enterprise. MEC thus focuses its community investment on the environment, the outdoors and conservation, "Iinking community investment to core business makes good business sense" (Denise Tachereau: Interview). 


\subsection{Obsenations}

This case study shows that MEC has developed policies to focus its operations on mainstreaming corporate social responsibility. The four pillars of MEC's sustainability policy focus on the issues which are important to the corporation, the industry, and also reflect issues mentioned in the literature review section of this report. The strategic view looks at the operation as a whole, how it conducts business, the product it sells and also ties into their community involvement. These are all the key areas of corporate social responsibility which shows its dynamic nature and how CSR can be applied not only to social or environmental initiatives for a community but also into the daily activities of the corporation.

The policy has internal regulations, activities and projects to guide its principles. In addition, selling outdoor products facilitates communication with stakeholders, in particular, CBOs and NGOs, since MEC is involved with the environment. MEC clients are demanding and care about the environment and people, in general, are concerned about the impacts businesses have on the environment. This in itself is a requirement to implement environmentally friendly regulations. However, since it is involved in the textile and footwear industry, it is sensitive due to the industry having a history of human rights abuses. An important point mentioned by the interviewees was that CSR for MEC goes beyond reputation management, which means that CSR is in the process of being mainstreamed effectively in MEC operations. They have moved beyond risk management 
and CSR is being implemented not merely because it is required to conduct business today, but because management and employees feel they must be socially and environmentally responsible, it is who they are and what $\mathrm{MEC}$ represents. Nevertheless, reputation and image control is important for MEC. For example, MEC sells a Nike product in its retail stores. It is a well known fact that Nike has had some controversies regarding labour issues in some factories. MEC is very clear and vocal that it is selling Nike products but that it is purchasing these products from factories that have been audited by Nike for environmental, social and labour compliance.

Through its strong approach to corporate social responsibility and high standards MEC is seen in Canada as an organization that is socially and environmentally responsible. The marketing emphasizes this message and its approach and activities are proof of its commitment to CSR. 


\section{THE OIL AND GAS INDUSTRY}

Oil and gas companies are very different to textile companies, one of the main differences is that oil companies are in the fossil fuel business, which is a non-renewable resource. Some oil experts seem to believe that there are limitless oil reserves around the world and that total oil reserves should be enough for many years at the current rate of consumption.

The rate of consumption, however, fluctuates and has a history of growth at a rate of about six to eight percent per year (Schumacher, 1999). This fact, together with oil and gas projects sometimes requiring the use of roads in remote places and thus the destruction of biodiversity and the impact on communities already causes significant criticism from civil society.

The oil and gas industry has suffered from negative publicity for many years. The battle between the general public, NGOs such as Greenpeace and the media against oil and gas companies escalated with the 1989 Exxon Valdez disaster and continued with Enron, an integrated energy firm. In addition, scrutiny was already affecting the industry on allegations of irresponsible social and environmental behaviour.

The scandals of energy companies have added to an already tarnished image. Oil and gas companies are faced with increased scrutiny in their global operations. The industry has been under examination for the way it has dealt with environmental and human rights issues. This occurred before the anti-globalization campaigns and corporate frauds. 
Investor confidence in the oil and gas industry has been shaken. Corporate governance and accountability of the private sector has been questioned and demands are being made to improve external and internal auditing and reporting (transparency). For example, in the United States, Congress recently passed the Sarbanes-Oxtez Act which requires companies that issue quarterly and annual reports to the Securities and Exchange Commission to have certified financial and other information signed by the executive and financial officers (Certification of disclosure by principal officers).

Oil and gas companies have been accused of behaving irresponsibly around the world causing irreparable damage to the society and the environment and causing major negative impacts. They have been accused of contributing to climate change, global warming, and encouraging lack of democracy, corruption and good govemance in the countries where they are producing.

The oil and gas industry has many different stages from preliminary identification and interest in developing a project to production and refinery. These steps have different effects on the environment and the communities. Roads are required in sometimes remote and ecologically sensitive areas leading to destruction of trees, plants and impacting the willife. Communities are disturbed during construction which may include population resettlement. Transportation causes dust and accidents can occur killing people, domestic animals and wildife. During drilling and production there are risks regarding accidents at the rig site and oil spills. In addition toxic waste is produced and in some countries the oil 
and gas industry can lead to increased crime and security problems, prostitution, increase of sexually transmitted diseases and corruption. These are some of the negative impacts of oil and gas companies, which need to be mitigated or minimized in order to improve the quality of life of the people and also improve the image of the oil and gas industry (Gary and $\mathbf{K a r l}, 2003$ ).

There are also positive impacts which can be achieved through the implementation of a comprehensive social and environmental program. Some of the positive impacts can include provision of employment, work for local suppliers, training and capacity building, dialogue between government and NGOs, community programs such as contribution to education and literacy, provision of electricity, water and leisure activities.

Regulatory reforms in different countries are now forcing the oil and gas companies to disclose information and there is a focus on good governance (both at the corporate and government level) and accountability. For example, the Sarbanes-Oxtez Act mentioned above. In addition, the oil producing countries have realized and recognized that the oil alone will not take them out of their poverty or improve their quality of life. This has not always been true. In the past in both Canada and in developing countries there were huge expectations that the oil and gas industry was going to solve their financial problems. For example, in 1937 T.D. Patullo the then premier of BC thought that "... when we strike oil our financial difficulties will be over" (Brody, 1988; p. 128). Goverments throughout the world have understood that oil is a depleting capital and that oil alone is not enough to 
ensure a better quality of life for the population. A diversified economy is required, with creative ideas, time and effort (Williams, 2002).

The industry has been trying to clean up its image due to increasing pressure from environmental and social groups. Oil and gas companies, in particular large international companies such as ExxonMobil, Shell, Chevron, and BP have made a conscious decision to adapt to the new corporate paradigm.

If oil and gas companies want to continue producing oil and gas they need to position themselves today in a very skeptical environment. Shareholders are demanding more corporate governance and accountability from the oil and gas companies due to the increased scrutiny by stakeholders. Companies are attempting to get attention from shareholders by performing in areas outside their operations scope and competencies; environmental sensibilities, human rights concerns, corruption, transparency, community relations and others. This is in addition to trying to attract quality employees and obtaining a license to operate in different countries and avoid oil and gas moratorium the Economist, 2002).

There is a paradigm shif in the oil and gas sector which stems from corporate level selfevaluation and an honest and true wilingness to contribute to society and the environment, from professional industry associations such as the Society of Petroleum Engineers. Pressure has also come from non-profit professional organizations such as the 
IPIECA which produced social and environmental guidelines for the oil and gas industry and the Coalition for Energy Market Integrity and Transparency (EMTT), a non-profit coalition of natural gas and electric utilities and consumers, oil and gas producers and energy service companies which appealed to the US government to investigate gas and electricity price manipulations. Multilateral organizations such as the UN, OECD and the World Bank have also produced industry best practices, guidelines and other instruments and non-governmental organizations such as Greenpeace, the Coalition for Environmentally Responsible Economies (CERES) and the Sierra Club have exerted enormous pressure on the industry. For example, CERES published 10 voluntary principles for corporate environmental conduct resulting from the Exxon Valdez incident (Wawryk, 2003). Finally governments in light of the increasing environmental, social and corruption problems have been imposing new regulations and stricter monitoring and control on the oil and gas companies.

The new paradigm shif has "forced" companies to develop policies which guide their envirommental and social initiatives. Govermments and professional organizations also have been required to produce regulations, guidelines and best practices to guide these companies. J. O'Reilly, Cherron Texaco Corporation Chairman and CEO said, "As the shope of our industry is chonging, our stakeholders are too. They're increasing in voice and in what they expect from us. Companies are accountable not only to employees, stochholders, neighbors, partners, and hosi governments but also to nongovernmental organizations, multilateral organizations, and community leaders on a much wider range 
of issues. Accordingly success is no longer determined solely by traditional financial or operational metrics. Today, we are held to new standards for corporate citizenship, human rights, and the environment that are no less rigorous thon the financial requirements of the investment community"(Williams, 2002: p. 25).

These comments are an indication that the oil and gas executives have understood the new rules of the game. The oil and gas industry has an awareness of the importance of mainstreaming environmental and social priorities into their corporate policies, decisionmaking and planning. 


\section{CASE STUDY 2 = COMPANY $X$}

\subsection{Introduction}

The second case study is a new Canadian company working in the oil and gas sector. Company $X$ is one of the world's leading independent oil and gas companies. The reason for choosing an oil and gas company is to be able to compare two very different industries; one in the retail business and the other in the extractive sector. Both companies are working in the international arena; MEC partners with local suppliers and contractors and company $\mathrm{X}$ sets up operations in different countries through direct investment. The challenges and problems faced by each company are very different, primarily due to their respective industries.

In this case study corporate social responsibility will be examined at the corporate and local level. The focus of the case study will be on the local corporate social responsibility program. A country hosting one of company X's operations has been chosen to examine corporate social responsibility and its implementation. The country chosen is in Africa, referred in this case study as country $\mathrm{A}$.

\subsection{Company Background}

Company $\mathrm{X}$ is one of the world's leading independent oil and natural gas companies. The company was created in 2001, when two Canadian oil and gas companies merged. 
Company $\mathrm{X}$ is North America's largest independent natural gas producer and gas storage operator. At the international level it is operating in Ecuador, Brazil, the Gulf of Mexico, Ghana, Country A. Australia, Yemen, Oman, Qatar and Bahrain, all at different levels of involvement, from preliminary market entry and research to full operation and production.

The company recently produced a new corporate constitution. The constitution highlights the company's vision which is to 'create a truly great company - one where quality work is the norm; where we stretch and strive to be the best we can be; and where great things are accomplished. Principles grace every decision and punctuate every interaction along our journey. Shareholders and other stakeholders support our endecvors because we have earned their trust and respect" (CEO - 2004).

\subsection{Corporate Social Responsibility}

The company recently created a new corporate responsibility policy because it believes that its reputation is critical to the creation of long-term value for shareholders. The policy commits the company to conducting business ethically, legally, and in a mamer that is fiscally, environmentally, and socially responsible, while delivering sustainable value and financial performance. The policy is a statement that encompasses the company's ethical, legal, financial, environmental, and social/community responsibilities. The corporate responsibility and intemational relations group in Canada is responsible for the development and roll-out of this policy. 
The policy reflects existing and emerging benchmarks of corporate responsibility, and is intended to help the company manage more effectively risks and reputation related to a broad range of corporate responsibility issues. In addition, the policy provides direction to the different departments regarding the type of activities and behaviour to pursue.

The Corporate Responsibility Policy is built on the following eight areas of commitment that reflect existing and emerging benchmarks of Corporate Responsibility:

"Leadership commitment is the first pillar of the corporate responsibility policy, making leaders accountable as role models to integrate corporate responsibility considerations into decision-making early and consistently. In addition, staff are required and expected to follow their example. Leaders are accountable for ensuring that appropriate structures are in place to effectively identify, monitor, and manage corporate responsibility issues and performance relevant to the business.

The second pillar is creating sustainable value, as a high-performance benchmark company, it strives to maximize value for shareholders. "Value" means both present and future values, arising from the pillors of value creation: high-quality assets, including solid credible reserves; strong finoncial management; and somal corporate governance. The company considers the creation of both short-term and long-term sustainable value in decision-making. 
The third pillar is governance and business practices, which is the commiment to maintaining the highest standards of integrity and corporate governance practices in order to ensure confidence in governance systems. These practices encompass not onty financial accounting but also include independent reserves evaluations. The compamy will implement changes, as required, to ensure ongoing alignment with leading corporate governance practices.

The company complies with all applicable laws and regulations in the countries where it operates, and with generally accepted business and accounting principles and practices and the rules of the stock exchanges on which the shares trade.

The company discloses material and reliable information to shareholders in a timely manner, subject to legal requirements and competitive constraints. It conducts its business in an open, honest, and ethical manner. It will not tolerate unlawful or methical behoviour in the workforce, including soliciting, accepting, or paying bribes or other illicit payments.

The compary recognizes the importance of protecting all assets of the company, inchuding finoncial, physical, human, social, environmental, and reputational assets, and will assess and manage risks to effectively steward these assets. 
Finally, the compony advises partners, contractors, and suppliers of the corporate responsibility policy, and will work with them to achieve consistency with this policy.

The fouth pillar is human rights, the company recognizes that governments have the primary responsibility to promote and protect human rights. The company shares this goal and will support and respect human rights within their sphere of influence.

The company will not take part in human rights abuse, and will not engage or be complicit in any activity that solicits or encourages human rights abuse.

In providing for the protection of company personnel and assets by public or private security forces, it will promote respect for, and protection of, human rights.

The fifth pillar is directly related with hman rights. It involves labour practices and states the issues which are relevant and important for the company. It will apply fair labour practices, while respecting the national and local laws of the communities where they operate. It will not engage in or tolerate unlawful workplace conduct, inchuling discrimination, intimidation, or harassment.

The company will not engage in forced or exploitative labour. 
100

The company will strive to provide local employment and economic opporthrities in the communities where it operates and will treat the workforce with dignity, faimess, and respect.

Environment, Health, and Safety (EHS) is the sixth pillar and is the commitment to protecting the health and safety of all individuals offected by activities, including its workforce and the public. It will not compromise the health and safety of any individual in the conduct of activities. The company will provide a safe and healthy working environment, and will expect the workforce to comply with the health and safety practices established for their protection. The company will safeguard the environment and will operate in a manner consistent with recognized global industry standards in environment, health, and safety.

In all operations, the company will strive to make efficient use of resources, to minimize its envirommental footprint, and to conserve habitat diversity and the plant and animal populations that may be affected by its operations.

It will strive to reduce emissions intensity and increase energy efficiency. For example, it applies high technology to enhance heavy oil recovery by applying technology that will reduce $\mathrm{CO}_{2}$ emissions, drilling directionally to reduce the environmental footprint, and using solar panels to capture and transmit well data electronically. 
The seventh pillar is stakeholder engagement and states the commitment to timety and meaningful dialogue with stakeholders, and addressing thetr legitimate issues and concerns within their sphere of influence.

The company states in the corporate responsibility policy that it will engage stakeholders clearly, honestly, and respectilly.

The final and eighth pillar is socio-economic and community development, this pillar emphasizes collaborative, consultative, and partnership approaches in community investment and programs, recognizing that no corporation is solely responsible for changing the fundamental economic, environmental, and social situation in a communty or country. Through activities, it will assist in local capacity-building and develop mutually beneficial relationships, to make a positive difference in the communities and regions where it operates" (Corporate Responsibility 2004, Internet).

The community investment program supports youth and education, health and wellness, environment and community development priorities. The company has already invested in excess of Cdn $\$ 8.3$ million in community programs in Canada and abroad.

In addition, the company has corporate guidelines and policies regarding ethics and integrity, environment, health and safety, a code of conduct, improper payment guidelines, and others. These policies are put in place by the corporate responsibility and international 
relations group based in Calgary and other deparments and are used as guidelines for undertaking business nationally and internationally with employees, suppliers, contractors, clients and other stakeholders. The group is responsible for internalizing and communicating some of these policies to all the different departments.

\subsection{International Corporate Responsibility in Country $A$}

Company $X$ has been involved in country $A$ since early 2002. The company now has an office in the capital and has a number of concessions where exploratory activities are well under way. The company has a community relations program headed by an advisor who is responsible for implementing the corporate responsibility policy through the community relations strategy and plan in country $\mathrm{A}$.

The community relations program was set up in country $A$ in early 2003 . The first activity undertaken by the community relations team was the planning and consequent implementation of an initial socio and environmental study undertaken in February and March of 2003. The study covered a southern basin and consisted of a first general identification of socio-economic and envirommental issues in the area.

After a few months in the country, management realized that due to the extreme poverty and needs in the country, operations would have a significant impact in the project area and the surrounding villages. In addition, operations would bring economic opportunity 
and potential growth but would also create some disturbance or stress in the social and environmental fabric of the area. It also realized that managing expectations would be a huge challenge, due to the lack of economic opportunities, and the fact that there was a different company already operating in another area of the country. Another challenge was to identify all the stakeholders and ensure that they were part of the information dissemination strategy. A specific plan was developed which encompassed the issues identified in the field and also reflected the corporate responsibility policy. As a result, management decided to hire an in-country community relations advisor who would be responsible for developing and overseeing the community relations program in Country $\mathrm{A}$. The program in Country $A$ is now guided by the CR Strategy and Plan developed in Country $\mathbf{A}$ and in Canada. In addition, the program reflects the objectives of the operations program in Country $\mathrm{A}$ and the corporate responsibility policy mentioned above.

The goal of the community relations program is to provide community relations and socioeconomic support to expedite the Country A project through lower transaction costs. This is done by implementing a community relations strategy and plan in Country $\mathbb{A}$. The objectives of the community relations program are to provide operational support so that Company X's drilling activities are undertaken in a socially and environmentally responsible manner so that the communities (and other stakeholders) are not negatively affected by Company $\mathrm{X}$ 's activities and to protect the company's image. 
The responsibilities of the community relations advisor include developing community relations annual plans (includes deliverables and proposed activities) and a community relations risk registry matrix, implementing and monitoring community relations plans, managing the community relations program in Country $A$ and community relations/environment monitors and other contractors, rolling-out the corporate responsibility policy, providing coaching and training to community relations/environment monitors and other contractors, liaising and maintaining a working relationship with NGOs and/or CBOs based in Country $\mathrm{A}$, liaising and maintaining a working relationship with project local authorities (from Governor to Land Chief), maintaining and providing effective project information and communication with Company $X$ 's community stakeholders, implementing the stakeholder engagement strategy in Country A, providing community relations information and/or briefing to Company $X$ 's contractors in Country A, developing community relations contract specifications for Company $X$ 's contractors, providing community relations advice, communicating and supporting staff, identifying, obtaining approval and managing community investment programs, liaising with the project team to ensure that the community relations program is understood and that the activities are appropriate and implemented in an efficient and effective manner, developing lessons learned and best practices and other relevant findings and reporting to the project team and head office to contribute to Company X's corporate memory, and finally contributing to socio-economic studies and surveys, as required by the project team. 


\subsection{Corporate Responsibility Activities in Country 4}

The company has been operating in Country A for a few years. In this time, the corporate responsibility policy has been implemented in various areas of its activities. The most important element has been the roll-out of the policy and making a presentation of the policy to all staff. Gradually the policy is being understood and applied, although there is still a lot of room for further buy-in within all the areas of operations. Some of the initiatives that have been undertaken and that match the corporate responsibility policy are provided below.

Leadership Commitment is the first pillar and as mentioned above. Top management from Calgary presented the corporate responsibility policy to the local team. Management has also implemented controls such as reporting documentation to track incidents, monitoring forms to monitor construction operations and non-compliance, and some contracts have CR specifications.

Govemance/business practices is another of the pillars mentioned in section 8.3 . In order to manage risks the company has developed a risk assessment tool covering all discipline risks which is updated on a regular basis. Reports have been shared with the local government which is an indication of good governance and transparency. In addition, government representatives are present in most of the project phases and project sites to monitor company compliance. Contractors have received presentations on the corporate 
responsibility policy and are also bound by the ethics and integrity policy and finally and most importantly for the communities, a fair and transparent compensation program was implemented using a method and rates previously approved by the government and the World Bank.

In regards to the human rights pillar, the company provides a weapon-free secure environment in the project location and has implemented a transparent and equitable hiring process.

The fifth pillar concerns labour practices and states that the company will make efforts to hire from the communities where it operates. In order to meet this pillar and to satisfy the needs and requests for employment from the communities, the Company has developed a community relations employment program and has hired people located close to the villages. In addition it lobbied with contractors to encourage them to hire manual labour, this included guards, kitchen helpers, bus boys, roustabouts, and wood cutters.

The sixth pillar is about the company's efforts to make efficient use of resources and minimizing the environmental footprint, safeguarding the enviromment and protecting the health and safery of individuals. This has been implemented by undertaking numerous studies and surveys aimed at minimizing operational impact. 
The studies and surveys have provided the following recommendations for minimizing socio-economic and environmental impact, hiring locals to monitor environmental and social impact during construction, consultation with communities to determine best location for access roads, avoiding sacred sites such as wetlands and trees after consultation with communities, identifying envirommental regulations to avoid cutting protected trees during construction, lobbying internally to approve corporate responsibility specifications for drilling and seismic contracts, respecting and supporting local traditions such as animal sacrificing, using existing seismic lines for required exploratory roads, and prohibiting the use of surface water.

The company has also initiated capacity building of local suppliers to help them understand EHS standards. Operations have been audited by external safety professionals to monitor compliance.

Stakeholder Engagement is the seventh pillar of the corporate responsibility policy. In line with the policy, the company has held numerous public information meetings with primary and secondary community stakeholders. In addition the company has been revising contimuously the stakeholder list, has held formal information meetings with NGOs, has prepared and disseminated an information bulletin and has undertaken information meetings with government and local authorities. Also the CR team has developed and implemented a database to keep track of all relevant issues which could, in the future, be shared with stakeholders. 
Some of the activities undertaken that fall under the socio-economic and community development pillar includes hiring community labour to cut felled trees so that the population can use the wood for fuel and also to maximize the use of natural resources used during construction. The company also attempted to minimize health impacts during construction and drilling and hired a local NGO to provide temporary health services by setting up a mobile clinic in different villages. The company wanted to leave something with the communities and funding a mobile health clinic was an option that made sense for all. It was something that was very helpful for the communities. It was also something that was catered for the drilling stage of the project. Lobbying for the installation of the water pump provided results and the company installed a water pump in one of the wells constructed by the company and used during construction. Herders and communities were provided with access to water during drilling and seismic operations.

Another area from the socio-economic and community development pillar is the capacity building of local suppliers in regards to EHS standards. The Company has very high intemational standards which unfortunately do not match the local reality. The company therefore is working with local suppliers to gradually build an understanding of EHS standards. This has proven to be a complicated and a lengthy process but results are slowly being achieved.

Another initiative which is part of several pillars is the constant environmental and social monitoring of the activities. This has been undertaken through local monitors and using 
monitoring tools such as alignment sheets. The alignment sheets are maps detailing envirommental, archeological and social issues which are given to construction teams to avoid or minimize the environmental footprint. Numerous reports and documents have been prepared, lessons learned and best practices have been developed and have contributed to the corporate memory on corporate responsibility.

\subsection{Challenges of Implementing Corporate Responsibility Policy}

The following section consists of providing information regarding some of the challenges which are associated with the implementation of the corporate responsibility policy.

Obtaining true commitment from management to develop guidelines and activities that reflect the corporate responsibility policy, "walking the talk", and resistance to change the "way it how been done in the past" has proven to be a major challenge at the early stages of the corporate responsibility implementation. Another very important challenge is identifying partners (stakeholders) that are committed to sustainable development and true dialogue, rather than merely stating the negative activities but offering few solutions to improve the situation. In many instances it seems that the negative criticisms were aimed at a hidden agenda to obtain a grant or employment. In addition there is lack of recognition by civil society of efforts undertaken towards corporate responsibility. This is probably directly related to the fact that some NGOs are looking for ways to obtain financial grants. 
Managing local authorities and community expectations is a very difficult challenge since expectations are enormous in an area where there are few private businesses, cxtreme poverty and very few employment opportunities. The communities and the local authorities are expecting the company to improve their quality of life in the short-term and are confusing a private sector initiative which is undertaking business responsibly with a development project undertaken by a development organizations or the government.

Incorporating useful and strategic corporate responsibility into the overall drilling planning process is an ongoing challenge. Although progress has been achieved in the implementation of programs and initiatives, buy-in of the corporate responsibility policy and its activities is still slow.

The extremely tight deadlines and high workloads for the employees based in Canada and Country $\mathrm{A}$ have not given a lot of room to plan activities and corporate responsibility is still not incorporated in most operations. The tight deadlines prevent planning adequate activities and developing strategic measures and instruments aimed at protecting the environment and maximizing the project social benefits.

A very complex challenge is the development of CSR performance measurement tools. This is still in its infancy and has proven to be very difficult to develop due to the lack of planning and lack of a yearly forward looking strategy. CSR performance measurement tools are instruments such as CSR key performance indicators. As mentioned previously, 
performance is difficult to measure due to the qualitative nature of CSR activities. For example, if there were no community labour strikes, could this be attributed to a socially responsible community program? As seen in the literature review section, it is hard to make a correlation between a community relations program and labour issues, NGO relationship and other CSR objectives.

Working with contractors and suppliers that understand the corporate responsibility policy, that are willing to undertake their activities in a sustainable manner, and that implement socially responsible recommendations is very difficult. Constant monitoring is required and a lot of time is spent on this issue. Improved partner selection is necessary as well as improved understanding of the corporate responsibility policy and an understanding that the practices implemented by contractors will reflect directly on the reputation of Company $\mathrm{X}$. 


\subsection{Future Considerations}

There are a number of CSR areas provided by the community relations advisor and the corporate responsibility and international relations group regarding areas where further development and improvement is required for CSR success.

Future improvement of the understanding and purpose of the Corporate Responsibility policy needs to be internalized in the company. The best approach is to encourage management to present the policy and to state its firm commitment to its implementation and assimilation. Further commitment from management is required and they need to understand that regardless of the types of activities undertaken by the company in the communities, there will be a social, environmental and economic impact and that further community investment is needed, but not necessarily through further capital investment.

Managing and obtaining commitment from suppliers and contractors more proactively is also something that requires consideration. This needs to be done through contract specifications and also lobbying and internal management commitment. Including corporate responsibility statements in the contracts signed with suppliers and contractors provides the CR department with some control over social and environmental decisions. It is a tool to measure what has actually been done by suppliers and contractors against what was said would be done and through this compliance or non-compliance can be measured. 
Further improvement is required in the involvement of civil society in the design and implementation of sustainable projects. According to company $X$, this is a long-term strategy which can be achieved through mutual understanding and respect, but both parties must be willing to participate honestly and actively. This is a difficult step which can be achieved through trust and willingness to cooperate together and understanding of the role of each other and acceptance of the benefits and achievements made by both parties. A survey undertaken by the SPE (the Society of Petroleum Engineers) in March 2004 , noted that the contribution to a constructive dialogue with other stakeholders was the number one priority for future NGO efforts (Arscott, 2004).

Some of the kind of activities and projects that can be undertaken with civil society are the development of meaningful training programs for community people. Civil society could include NGOs and training institutes. Employment is a recurring request made by local people and since the company has high standards and requirements a practical capacity building program is needed for current and potential employees. Strengthening the capacity building of local suppliers is another area requiring further effort.

Directly related with stakeholder engagement and relationship building is the need to improve disclosure of information to stakeholders and the need to improve the disclosure information tools. This is a topic which is discussed extensively in the literature review of this report and is especially important for the extractive industries and is increasingly a 
requirement or guideline from intemational financial institutions such as the International Finance Corporation (IFC).

Including CSR in job performance evaluations and job descriptions for all employees provides means to negotiate with staff and can be used as tools to encourage staff to be socially and environmentally sensitive.

Finally, the company needs to encourage tripartite dialogue between government, civil society and private sectors. Similar to the other future considerations in regards to civil society, this is a long-term process which requires commitment, approval and trust from all parties.

\subsection{Impacts of Being Socially and Environmentally Responsible}

Company $\mathrm{X}$ is undertaking exploratory drilling activities in a very poor country in Africa. This creates a lot of international exposure and visibility, in particular in areas where there is violence and ethnic or religious conflict. International oil and gas companies operating in these countries need to be careful if they want to continue operating in these countries and are concerned about their image and reputation. According to the community relations advisor, the benefits of being socially and Environmentally Responsible goes beyond doing the right thing. 
The company believes that its reputation is critical to the creation of long-term value for its shareholders. In addition, it has recognized that reputation and social approval (social license to operate) are important elements of sustained financial success. This message has been passed by top management on numerous occasions, both internally to the company and also externally in public events such as the Seventh International Conference on Health, Safety, and the Environment in Oil and Gas Exploration and Production held in March 2004.

The company is also well aware of the risks associated with international ventures, in particular in developing countries. Some of the risks include security, safety, reputation, government, financial and other risks. Being socially and environmentally responsible attenuates some of these risks and also provides a license to operate in the region and also possibly in other regions and neighboring countries. Corporate responsibility for the company avoids delays due to negative publicity, riots and strikes, weakened negotiations, damaged public image, and avoids financial repercussions. Thus improving decisionmaking (or making it easier) and increasing a projects' long-term viability. It also has the added benefit of enhancing the quality of life of affected villages and other stakeholders.

The literature review has shown the importance given to corporate social responsibility by multinational organizations, non-govermmental organizations, the media and the public in general. Increasingly, communities have access to information about their rights and what other companies are doing in similar circumstances. Involving the communities and the 
public has provided community support for oil and gas projects and the company believes it avoids social unrest (civil society is looking at the private sector to contribute to improving their quality of life).

Increasingly multilateral organizations such as the World Bank are getting involved in private sector initiatives. Similarly, companies are also willing to work with these types of organizations to leverage the financial and reputation risk. Being socially and environmentally responsible gives the company the means to be able to work as partners with international organizations such as the World Bank's International Finance Corporation (IFC) and satisfy local economic, social, regulatory interests and World Bank guidelines.

Community Relations in Country A would like to support, as much as possible, the local economy. This can be done in the long-term by working with men and women from Country $\mathrm{A}$ and building their capacity, using local counterparts, buying locally thus encouraging the local economy, and finally encouraging suppliers and contractors to work with locals and buying from the communities.

The implementation of the corporate responsibility policy has allowed the company to take into consideration the opinion of the communities and implement initiatives which are required by the communities. In addition, public information and stakeholder engagement allows for community planning, such as getting local suppliers ready. It allows the 
company to contribute to the needs of the people, in particular in rural areas where employment opportunities are scarce. This builds a positive corporate image and demonstrates commitment to Country $\mathrm{A}$ and the communities.

Corporate responsibility activities have provided benefits to the people of Country $\mathrm{A}$. For example, local employment has been created. In addition, some local suppliers were used for different services, including the provision of food and other products. Also, some communities benefited from temporary water supply and medical attention and a water pump was installed near a village. There is some recognition by local authorities and some local NGOs of the efforts made by company $X$, although they mentioned that there is room for improvement since there are huge expectations and a lot of reliance on the company to be part of the overall poverty alleviation of the area.

Finally, according to company $\mathrm{X}$, there are substantial demands made by the general population regarding hiring of local people and using local suppliers instead of foreign companies. This is one of the main areas of social benefits that can be provided in this country since other than oil and gas, there are very few opportunities for employment. Using local labour and local companies makes good business sense, in addition encouraging local suppliers is part of the corporate responsibility policy. Using local resources leads to significant savings on accommodation and transportation if the right resources are found. Increasingly Country $A$ has university graduates that can fulfill many management, technical and administrative functions. If hiring locally, it is important for 
companies to follow legal requirements for hing and especially for dismissing local workers.

\subsection{Lessons Leamed}

There is a reluctance to implement a forward and global looking approach due to internal bureaucracy and lack of in-house experience and/or corporate memory in the international arena. This is one of the major challenges which can be corrected with further training and hiring of expert consultants. This causes some setbacks since the criteria, expectations and tolerance levels of staff do not match the local realities. Employees and contractors having previous international experience are required.

Internal acceptance of community relations and corporate responsibility is a lengthy process. Internal lobbying is one of the most time-consuming aspects of the community relations program. The role of "educating" the employees and contractors on being socially responsible has been left to the community relations group. This notification should be given by top management and management from each discipline, since they have more leverage. Top management commitment shows a more "meoningful" assurance and management support for $\mathrm{CR}$ leads to a greater internal acceptance of the CR program. It is also important for all employees to understand that $C R$ is a long-term process where commitment is achieved, but slowly. 
Another lesson leamed is the huge expectations by the communities and local authorities. Since Country $\mathbf{A}$ is a very poor country with high unemployment levels and very little foreign investment, the people of Country $A$ are looking at Company $X$ as their only source of poverty alleviation. Unrealistic demands are constant, requiring a lot of effort, time and public information. Clear project scope and project extent must be communicated to the public in general and communities, local authorities and NGOS.

Personal relationship with individuals in the company leads to some CR support and personal commitment from leaders is required. The company also needs to establish accountability for the implementation of the corporate responsibility policy to gradually mainstream CR in the project. This is necessary so that management and other employees understand the importance given to CSR by leaders and as a "lead by example" strategy.

Lobbying internally and externally with key employees and contractors has provided some results. For example, community employment is one of the main necessities in the project area and through encouragement and lobbying, the company was able to provide temporary employment opportunities in the project area. This was very well received by the people, village chiefs, and other high level authorities.

Currently, the company uses a first party certification classification which is not effective, since international financial institutions and civil society are raising comments regarding transparency and accountability. Third party certification would leave less room for 
criticism and cynicism regarding accountability, govemance and transparency. As mentioned is section 3.7 of this thesis certification is a tool used by corporations in an attempt to demonstrate good corporate transparency and governance.

The benefits and value added of being socially responsibility is not well understood by the in-country team and requires a lot of lobbying by the CSR group. Corporate responsibility is given a low priority at the drilling phase. Linking job performance and responsibility with corporate responsibility might improve this understanding.

Briefing on corporate responsibility must be done on a frequent basis and probably would be better understood if the head office would be involved in transferring this message. This will need to be done on an on-going basis. Incorporating corporate responsibility in the planning process will improve this understanding and will allow more time for implementation.

Adequate and strategic timing is also another very important lesson learned. The project needs to incorporate $C R$ in the overall planning process to ensure a better implementation of $\mathrm{CR}$ activities. For example, communities need time to assimilate information that is being disseminated by the $C R$ group. In addition, it is important for messages to be consistent and, where possible, the program planned should not change, otherwise it causes confusion and distrust with stakeholders. Time is also required to develop 
activities, consult with the communities and identify community employment and local suppliers that have the requirements needed by the company.

Finally, including corporate responsibility specifications in supplier and contractor contracts and obtaining management commitment has proven to be useful to mainstream corporate responsibility in the operations and obtaining buy-in from staff and contractor personnel.

\subsection{Observations}

In this case study it is apparent from the description of the corporate responsibility policy that at the corporate level the organization has made policy commitments to being socially responsible. The preliminary steps mentioned in the literature review section of this thesis are well in place. The constitution recognizes the shareholders and stakeholders and is clear that the principles the company has are recognized at the policy level. It is apparent that there is a strong understanding by corporate services of the paradigm shift in industry and that being an organization that is responsible gives the company the social license to operate.

The corporate responsibility policy encompasses key topics which are discussed by academia, activists, corporate responsibility leaders, lobbyists, and businesses. The policy mentions accountability, transparency, good governance, human rights, and environmental 
footprint. It recognizes stakeholder engagement, community relations, and many other subjects which are key elements of a corporate responsibility policy. These are all indications that the corporation has understood the new changes.

The policy is new and it will take some time to trickle down so that it can turn into regulations, rules, guidelines and practices, and further into activities and projects so that all stakeholders, including employees and contractors have a better understanding of corporate responsibility. The process and tools, as shown in the case study, are in place. With continuous effort by the people responsible for implementing them, the effects of corporate responsibility will be felt and understood by more stakeholders. 


\section{BENEFITS AND LIMITATIONS}

\subsection{Benefits}

The development of lessons learned is an important management information tool used by companies and corporations to adjust their programs and policies. In addition, case studies are useful means to obtain qualitative information on the historical background, procedures, processes and activities of companies. Descriptive methods of analysis provide value added to companies to determine what are the most effective ways to operationalize and institutionalize corporate social responsibility strategies.

The information gathered in this research can be used by corporations, development agencies, associations and consultants alike to assist companies in furthering their corporate social responsibility goals and in turn contribute to the amelioration of the standard of living of communities in developing countries.

This thesis has contributed in understanding how two companies working in the international arena are implementing CSR and provides guidance for other companies considering incorporating CSR internationally. The case studies have provided examples of the type of policies that are used by companies and the key areas highlighted in these policy statements. In addition, lessons learned regarding activities or procedures that work have been described together with the challenges. Examples regarding activities were provided which can be used as guidelines for other companies.

The results of this study can provide head office and field managers some insight into some of the activities on CSR undertaken by companies, the impact of undertaking CSR 
both for stakeholders and the company, and the procedures used to implement CSR. In addition, this research contributes to the CSR literature and validates related research covered under the literature review section of this thesis.

\subsection{Limitations}

Case studies cannot be used to make statistical conclusions or scientific generalizations, however, they provide a basis for further research and qualitative information can be used by companies as lessons learned.

The study used subjective perceptions to examine a number of variables. Many factors that cannot be controlled affected these results. For example, the interviewees perceptions, mood, etc. The information gathered was therefore based on the opinion of a few people and thus is subjective and probably does not represent the whole spectrum of CSR activities for each company. However, the most important objective was to understand the tendency rather than exact measurements and obtain lessons learned and other qualitative information.

The methodology used in the case studies did not include options to discuss negative aspects of CSR since it is a sensitive issue and the researcher thought that the interviewees could be reluctant to provide this kind of information. Also, the lessons learned did not focus on negative impacts, evaluation or judging the activities undertaken by the companies rather it focused on obtaining lessons to improve CSR implementation. This fact creates a somewhat biased approach towards CSR since it was neither an evaluation nor assessment and the information was not verified in writing, other than obtaining information from company's websites and yearly reports. It is important to clarify that the 
results of the correlation between performance and social responsibility cannot be conclusive since there are a number of variables that can contribute to performance which were not examined in this thesis and which were not the objectives of this thesis.

Another possible limitation is the fact that the researcher is working in the corporate social responsibility area and there could have been some biases regarding the benefits of corporate social responsibility and interpretation of research data.

Finally, it is impossible to generalize the case studies to other industries or companies due to the limited number of cases. It is also important to understand that the companies studied were not only in different industrial sectors but they were also at different stages of CSR implementation. In addition, their strategies of involvement in international activities were also different. For example, MEC is involved in international business through supplier partnership collaboration and Company $X$ has a direct investment in country A. 


\section{FINDINGS}

There are indications from the discussions in this paper that domestic and international stakeholders want companies to behave more ethically and increasingly prefer purchasing products and services from ethical corporations and good corporate citizens.

Similarly, corporation leaders are becoming more aware of the importance of CSR and their commitment to meet the economic, social and environmental expectations of stakeholders. As mentioned, corporations in particular large multinationals can no longer act irresponsibly towards social and environmental issues. It is also clear from the case studies presented in this paper that corporations are increasingly aware of the importance of engaging stakeholders and have realized that they are no longer the only players in the economic development of society.

The industries discussed in the case studies are very different; MEC is a retailer selling outdoor products manufactured by its garment and footwear subcontractors and Company $X$ explores and produces oil and gas. One of the obvious differences is that garment and footwear in general employs mostly women, whereas the oil and gas employs mostly men, especially in developing countries. This is probably due to the perception that women might not want to work in more physically demanding environments. Regarding CSR, there are differences in issues of concern for each individual industry. Due to media and civil society lobbying, the main social and environmental issues for the garment and footwear industry are labour issues, in particular regarding child labour, working conditions, working hours and salary. For the oil and gas industry the issues which are highlighted primarily by the media and civil society are environment issues, in particular regarding climate change, global warming, oil spills and wildlife and vegetation impacts. 
This does not mean that the other social or environmental issues are not important in each industry but it reflects the importance given to these issues by the public. Another difference in the industry is that the oil and gas industry deals with a non-renewable resource (fossil fuel) and the textile and footwear industry with renewable resources (e.g. cotton, leather, etc.). The case studies have shown that there are clear differences in the approaches adopted by MEC and Company $\mathrm{X}$ towards CSR. MEC is guided by the company's Guiding Statements and Sustainability Policy. The CSR term used by the company is social and environmental management system which is promoted by the Social and Environmental Responsibility Group. Company X, however, is guided by the Corporate Constitution and the Corporate Responsibility Policy and the preferred CSR term is Corporate Responsibility. These efforts are led by the Corporate Responsibility and International Relations Group. Regardless of the term used or policy, it consists of recognizing the importance of contributing towards environmental and social sustainability, of mainstreaming and integrating these aspects into the business, rather than ad hoc or philanthropic activities. It is viewing CSR as a long-term approach and part of the corporation's values.

The sustainability policy promoted by MEC focuses on four pillars which are business operations, product sustainability, sustainable consumption and community investment. All these different pillars cover issues which are of importance to MEC and are also probably aimed at mitigating some of the past controversies in the industry. The issues covered are the envirommental and social concerns of internal business operations, specific product issues regarding social and environmental sustainability, consumption needs of members and community investment. 
Company $\mathrm{X}$ promotes the corporate responsibility policy which focuses on eight different pillars. The pillars are leadership commitment, sustainable value creation, governance and business practices, human rights, labour practices, environment, health and safety, stakeholder engagement and socio-economic and community investment. The issues covered under these broad topics are accountability of management, good governance, creating value for shareholders, governance and accountability of its operations, security issues, labour practices, environment, safety and health of employees and other stakeholders, transparency and information dissemination with its stakeholders and community investment. Similar to MEC, the policy areas of focus probably stems from the industry being criticized by civil society. For example, chapter 7 of this paper showed that governance and accountability are two of the main topics under criticism due to past industry behaviour and recent corporate frauds and thus company $\mathrm{X}$ has an area in their corporate responsibility policy to cover this topic.

There are some differences in the policies of each individual company. For example, it is important for company $\mathrm{X}$ to create value for its shareholders since energy companies need to attract investors. MEC has a similar area, but is more concerned with member needs through its sustainable consumption area (members are the investors for MEC). Other differences in areas include the focus given by company $X$ to stakeholder engagement since the industry is heavily criticized for not being transparent and behaving socially and environmentally inappropriately. Also, MEC has integrated social and environmental issues in its 4 sustainability policy areas (pillars), whereas Company $\mathrm{X}$ has a specific environment area (pillar 6) and social area (pillar 8) to cover environmental and social concerns. 
Other than these policies each company has created additional policies. For example, MEC has a sourcing policy and supplier code of conduct and Company $X$ has an EHS policy, ethics and integrity policy and others developed as a framework to provide direction to employees, contractors and suppliers.

The impacts and/or benefits of CSR for both companies are also different. MEC gives a stronger emphasis on employees and customer loyalty, probably due to the importance of customer and client relations in retail businesses. Company $\mathrm{X}$, however, focuses more on company reputation, managing risks, community involvement and obtaining a license to operate. An important point mentioned by $\mathrm{MEC}$ is that being socially responsible at MEC goes well beyond reputation management. For company $\mathrm{X}$, however, reputation management is one of their objectives of being socially responsible. The differences between these two companies are probably due to the different sectors where they operate and perceived impact of their operations. MEC as a retail business is less susceptible to criticism in terms of its operations and its impact on the environment and society, but needs to be more aware of subcontractors, customer needs regarding products and services and employee relations to improve productivity, morale, and loyalty since these employees are also potential customers. In addition, MEC customers are highly interested in social and environmental issues. Company $X$, as mentioned previously deals with a nonrenewable resource and is in an industry that has historically been criticized for its lack of social and environmental responsibility.

An important difference between both companies which demonstrates the different level of internal CSR assimilation is that MEC has recognized that everything it does has an impact on the planet, the environment, communities, and other things. MEC has recognized it and has incorporated this recognition in the sustainability policy. It is interesting to note that 
for Company $\mathrm{X}$, this recognition is still absent and internal acceptance is still something that the CR group needs to lobby to obtain management recognition. The group has recognized it needs to do more briefings and lobbying with staff to accept the fact that operations and activities have an impact on the planet, the environment and communities.

Company $\mathrm{X}$, a company operating in the extractive sector, has a greater impact on the enviromment and communities and therefore needs stronger involvement regarding consultations, public information sessions, stakeholder engagement, community investment, managing risks and obtaining a social license to operate. Thus reputation and risk management is important. The company's reputation is at stake, especially when operating in developing countries where there is greater scrutiny from NGOs and other members of civil society. Therefore, it is easy to understand the benefits and/or impacts perceived or achieved by each individual company since they are operating in very different sectors.

In regards to lessons learned both companies mentioned the commitment required from senior management and the amount of time required internally to lobby for corporate social responsibility (or the term used by the company to refer to CSR). This information was somewhat surprising since MEC has been operating for a number of years and is considered a pioneer in terms of its environmental and social commitment. It is not surprising for Company $X$ to have as a lesson learned that the commitment required by senior management is inadequate since Company $X$ is a fairly new firm and is therefore still in its infant stage in regards to CSR and the internal understanding of CSR. In addition, oil and gas companies tend to have less flexible and progressive management. 
The CSR areas of focus by the companies are also very different; MEC has committed substantial resources towards the implementation of community and environmental activities mostly focusing on the environment. Company $X$, in contrast, has focused more on stakeholder engagement, community investment and environmental and social planning to minimize the environmental and social footprint. This is due to company $X$ being a relatively new player in the industry and the increasing scrutiny by NGOs and other members of civil society with oil and gas companies. In regards to $\mathrm{MEC}$, the environment is important for the company since it is part of the corporate values and core business and since the company is involved in the outdoor business and clients usually tend to be people that are concerned with the environment. Company $X$ has a strong focus internationally due to its involvement in country A. Stakeholder engagement and community investment are also important since they are part of the permit and license required (informally) to operate. The geographic location of the community investment programs is also different. Although not covered in this document, company $\mathrm{X}$ has community investment programs in Canada, South America and Africa. MEC however, concentrates its community investment programs in Canada since it does not operate internationally. Its international efforts are focused on ensuring that suppliers comply with the outsourcing policy and supplier code of conduct.

Two surprising topics which were not mentioned by either company in the lessons learned sessions of the interviews were governance and accountability, especially since they are both operating internationally. Both govemance and accountability are increasingly becoming important topics discussed in corporate meetings and conferences ${ }^{2}$. Governance

\footnotetext{
${ }^{2}$ SPE International Conference on Health, Safety and Environment in Oil and Gas Exploration and Production, New Horizons in HSE: Dialogue, Commit, Deliver, 29-31 March 2004, Calgary, Alberta.
} 
and accountability were part of Company $X_{2}^{\prime}$ 's corporate responsibility policy, but were not mentioned as a lesson learned.

Summarizing, both companies mentioned senior management involvement as being critical to CSR implementation and internal buy-in and both have policies in place regarding corporate social responsibility, including a code of conduct. In addition, internal lobbying for corporate social responsibility commitment is an on-going process in both companies, requiring efforts from the CSR departments.

The terminology and interpretation of CSR used by each company are different; however there are similarities in terms of their environmental and social commitment. Both companies mentioned their corporate values and policies regarding their commitment to CSR. Company $\mathrm{X}$ gives a stronger emphasis, in practice, on stakeholder engagement and community investment. MEC places a stronger emphasis on employee relations and community investment, in particular regarding contributions to environmental undertakings.

Finally both companies mentioned performance measurement as a challenge. Overall, both companies have embraced corporate social responsibility and it has become integrated in their way of doing business. They are in different sectors and at different levels of CSR implementation and their activities and actions reflect this reality.

The table in the following page summarizes the areas of CSR involvement mentioned by both companies. The areas of involvement have been classified according to programs; community involvement, stakeholder engagement, impact assessments and support, 
accountability, transparency and governance, employees, environment, and supplier and contractor relationship.

Table 2 - CSR Areas for MEC and Company X by Program

\begin{tabular}{|c|c|c|}
\hline \multicolumn{3}{|c|}{ Summary of CSR Areas of Involvement for both Companies } \\
\hline Procran & 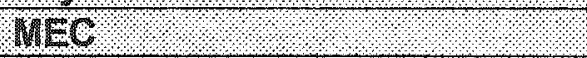 & Company X (in country A) \\
\hline $\begin{array}{l}\text { Community } \\
\text { Involvement }\end{array}$ & $\begin{array}{l}\text { Community investment } \\
\text { Comprehensive social and } \\
\text { environmental } \\
\text { information } \\
\text { Environmental investment in } \\
\text { communities } \\
\text { Community investment is } \\
\text { located mostly in Canada }\end{array}$ & $\begin{array}{l}\text { Community employment } \\
\text { Community } \\
\text { suppliers/contractors } \\
\text { Community investment } \\
\text { Social and environmental } \\
\text { newsletters } \\
\text { Community relations training for } \\
\text { staff and contractors } \\
\text { Community investment is } \\
\text { located in Canada and all } \\
\text { countries where they operate }\end{array}$ \\
\hline $\begin{array}{l}\text { Stak } \\
\text { Enga }\end{array}$ & $\begin{array}{l}\text { Public } \\
\text { information/consultation } \\
\text { Internet information } \\
\text { Stakeholder formal and } \\
\text { informal meetings }\end{array}$ & $\begin{array}{l}\text { Public information/consultation } \\
\text { Stakeholder identification } \\
\text { Stakeholder newsletters } \\
\text { meetings }\end{array}$ \\
\hline $\begin{array}{l}\text { Impact } \\
\text { Assessments and } \\
\text { support }\end{array}$ & $\begin{array}{l}\text { Socio-economic and } \\
\text { environmental support for all } \\
\text { departments }\end{array}$ & $\begin{array}{l}\text { Socio-economic and } \\
\text { environmental screening } \\
\text { Social and environmental impact } \\
\text { assessments } \\
\text { Socio-economic and } \\
\text { environmental support for all } \\
\text { departments }\end{array}$ \\
\hline $\begin{array}{l}\text { Accountability, } \\
\text { Transparency and } \\
\text { Governance }\end{array}$ & $\begin{array}{l}\text { Vision and values } \\
\text { Monitoring and control } \\
\text { Codes of conduct } \\
\text { Supplier code of conduct } \\
\text { Outsourcing policy } \\
\text { Sustainability policy } \\
\text { Intemal and extemal } \\
\text { communication of codes of } \\
\text { conduct and policies } \\
\text { Information sharing thorough } \\
\text { websites and meetings } \\
\text { Report dissemination to the } \\
\text { board of directors, employees } \\
\text { and the public } \\
\text { Internal and extemal audising }\end{array}$ & $\begin{array}{l}\text { Vision and values } \\
\text { Monitoring and control } \\
\text { Codes of conduct } \\
\text { Corporate responsibility policy } \\
\text { Internal and extemal } \\
\text { communication of codes of } \\
\text { conduct and policies } \\
\text { Information sharing thorough } \\
\text { websites, newsletters and } \\
\text { meetings } \\
\text { Report dissemination to the } \\
\text { board of directors, employees, } \\
\text { government, } \\
\text { organizations, and some to civil } \\
\text { society } \\
\text { Internal auditing }\end{array}$ \\
\hline Employees & Workplace diversity & Training and capacity building of \\
\hline
\end{tabular}




\begin{tabular}{|c|c|c|}
\hline Progran: & MEO & comoany X in country A \\
\hline Employees & $\begin{array}{l}\text { Work-life balance } \\
\text { Training and capacity building } \\
\text { of stafi } \\
\text { Employee participation in } \\
\text { decision making } \\
\text { Health and safety programs } \\
\text { Employee questionnaires satisfaction }\end{array}$ & $\begin{array}{l}\text { staff } \\
\text { Employee participation in } \\
\text { decision-making Health and } \\
\text { safety programs }\end{array}$ \\
\hline Environment & $\begin{array}{l}\text { Environmental products and } \\
\text { services } \\
\text { Information on environmental } \\
\text { products and services } \\
\text { Environmental product } \\
\text { stewardship } \\
\text { Environmental } \\
\text { workplace } \\
\text { Environmental sensitive } \\
\text { stores } \\
\text { Energy efficient programs } \\
\text { Internal and external } \\
\text { recycling programs } \\
\text { Waste management plans } \\
\text { Resource efficient programs }\end{array}$ & $\begin{array}{l}\text { Environmental screening and } \\
\text { evaluations } \\
\text { Environment monitors } \\
\text { Mitigating and minimizing } \\
\text { measures } \\
\text { Alignment sheets } \\
\text { Waste management plans } \\
\text { Environment protection plan }\end{array}$ \\
\hline $\begin{array}{l}\text { Supplier and } \\
\text { Contractor } \\
\text { Relationship }\end{array}$ & $\begin{array}{l}\text { Social and environmental } \\
\text { specifications for contractors } \\
\text { and suppliers } \\
\text { Supplier and contractor } \\
\text { screening } \\
\text { Supplier code of conduct and } \\
\text { outsourcing policy } \\
\text { Supplier training on policy } \\
\text { and code of conduct } \\
\text { compliance } \\
\text { Intemal and extemal social } \\
\text { and environmental auditing }\end{array}$ & $\begin{array}{l}\text { Social and environmental } \\
\text { specifications for contractors } \\
\text { and suppliers } \\
\text { Supplier and Contractor training } \\
\text { on community relations and } \\
\text { environment, health and safety } \\
\text { Internal environmental } \\
\text { monitoring }\end{array}$ \\
\hline
\end{tabular}




\section{CONCLUSION}

The process of gathering lessons learned and best practices and documenting them is important for obtaining a deeper understanding on CSR and obtaining internal and external buy-in. It is hoped that this thesis has contributed to the process of acquiring insight regarding CSR implementation, its implications, experiences and challenges so that companies can best appreciate the importance of CSR and how best to apply CSR activities into their operations. Regarding NGOs, it is expected that they can contribute to CSR by providing realistic and valuable recommendations. In addition, it is hoped that they agree to dialogue with companies and where warranted recognize the efforts made by the private sector towards social and environmental sustainability. It is also important for the private sector to understand and recognize the value and historical experience civil society has regarding environmental and social sustainability and the contribution civil society can make to improve the envirommental and social standards of the companies.

Further research is suggested in this very important and dynamic subject. Some suggestions could be to focus specifically in one area of corporate social responsibility, for example, on community investment, governance or stakeholder engagement. Another possibility is to undertake research describing some failures, industry's negative impacts, operations' negative impact and what management could have done to improve their operations. However, it is recognized that this information might be difficult to gather since some corporations might be reluctant to discuss this kind of outcome.

One obvious area for further study is linking performance to corporate social responsibility. A final area could be to do research on the intemal and external 
requirements for progressing and advancing on CSR, such as including CSR in job performance evaluations, corporate recognition programs, bonus or profit-sharing, amongst others. In addition, it could be useful to focus only on one industrial sector and describing their challenges and lessons learned.

The case studies have clearly shown that although there are parallels in the way companies are behaving there are no blue-prints. There are no international laws, policies, or regulations that can be applied specifically to each industry and that can fit each company; each case is different. The two companies studied have developed their own policies to provide direction to their activities and operations. These activities are clearly different in each case. There are also similarities in regards to the companies' overall corporate social responsibility goals. This is probably linked to the corporate social responsibility movement and pressure from civil society.

Overall, it can be said, based on the two case studies presented in this paper that the companies have understood what it means to be a responsible organization and the importance of developing programs and investments in their areas of operations. In addition, the strategic nature of CSR has been understood and tools such as corporate statements and policies have been put in place for the overall goal of contributing to the achievement of economic, social and environmental sustainability. 
References

Abott, W.F., and Monsen R. (1979). On the Measurement of CSR: Self Reported Disclosure as a Measure of Corporate Social Involvement. Academy of Management Journal, 30, 277-296.

Alperson, Myra (1998). Building the Corporate Community Economic Development Team. The Conference Board Inc., New York, USA.

API/TPIECA (2003). Compendium of Sustainability Reporting Practices and Trends for the Oil and Gas Industry, IPIECA, APRI, 2003.

Arscott, Lyn (2004). Progress and Challenges for Health, Safety, and the Environment in Exploration and Production, Journal of Petroleum Technology, July 2004.

Aupperle, K.E., and Acar, W. (1993). Reconfiguring the Corporate Social Responsibility Construct. Presented to the Academy of Management Social Issues Management Division for the 1993 Atlanta Proceedings, Atlanta, GA.

Beesley, Michael and Tom Evans (1978). Corporate Social Responsibility: A Reassessment. Croom Held Ltd, London, UK.

Bernard, C.I. (1938). The Functions of the Executive. Cambridge, MA: Harvard University Press.

Blake, D.H. (1980). The Management of Social Policy by Multinational Corporations: A Research Agenda, in L.E. Preston (ed.,), Research in Corporate Social Performance and Policy, Vol. 2 (JAI Press Inc., Greenwich, CT).

Bloom, Richard (2003). Ethical Funds Change with the Times. The Globe and Mail's Weekly Report on Personal Finance, The Globe and Mail, Saturday, March 8, 2003, pp. $\mathrm{Cl}$ and $\mathrm{C}$.

Bowen, H.R. (1953). Social Responsibilities of the Businessman. New York: Harper and Row.

Brody, Hugh (1988). Mops and Dreams. Indians and the British Colmbia Frontier. Douglas and Mcintyre, Vancouver/Toronto.

The Business Roundtable (1981) Statement on Corporate Responsibility, Washington, D.C.: The Business Roundtable, October. 
Canadian Business for Social Responsibility (2001). An Overview of Selected Canadian, European and International Practices. CBSR, Vancouver, Canada.

Canadian Business for Social Responsibility (2003). Corporate Social Responsibility Meeting at the University of British Colombia.

Cairoli, Laetitia (1999). Garment Factory Workers in the City of Fez, The Middle East Journal, Volume 53, Number 1, Winter 1999.

Carroll, A.B. (1979). A Three-Dimensional Conceptual Model of Corporate Social Performance. Academy for Management Review, 4, pp. 497-505.

Carroll, A.B. (1991). The Pyramid of Corporate Social Responsibility: Towards the Moral Management of Organizational Stakeholders. Business Horizons, 34(4), 39-48.

Carroll, A.B. (1999). Corporate Social Responsibility: Evolution of a Definitional Construct, Business and Society, Volume 38, No. 3, September, pp. 268-295. Sage Publications.

Centre for Policy Dialogue ((2002). National Dialogue on Corporate Responsibility in Bangladesh: Where do we Stand? August 4, Dhaka, Bangladesh - CPD and Tata Energy Research Institute - Europe (TERI - Europe).

Clutterbuck, David and Deborah Snow (1990). Working with the Community - A Guide to Corporate Social Responsibility, Published by George Weidenfeld and Nicolson Ltd, London, UK.

Cochran, P.L. and R.A. Wood (1984). Corporate Social Responsibility and Finomcial Performance. Academy of Management Journal, 27, pp. 42-56.

Collins, J.C. and J.I. Porras (1995). Built to Last, Successful Habits of Visionary Componies. Century, Random House, London.

Committee for Economic Development (1971). Social Responsibilities of Business Corporations. New York: Author.

Cragg, Wesley and Alan Greenbaum (2002). Reasoning about Responsibilities: Mining Compony Managers on What Stakeholders are Owed. Jounal of Business Ethics, 39, pp. $319-335$.

Davis, K. (1973). The Case for and Against Business Assumption of Social Responsibilities. Academy of Management Joumal, 16, June, pp. 312-322. 
De La Cruz Deniz-Deniz, Maria and Juan Manuel Garcia-Falcon (2002). Determinants of the Multinationals' Social Response. Empirical Application to International Companies Operating in Spain, Joumal of Business Ethics, 38, pp. 339-370.

Dey, Peter (1994). Where were the Directors". Dey Chair of the Corporate Governance Committee of the Toronto Stock Exchange. Toronto Stock Exchange.

Donaldson, John and Guido A. Gini (1990). Case Studies in Business Ethics, Prentice Hall, Englewood Cliffs, New Jersey.

Economist, (2002). "History Shows the Anglo Saxon Corporations to be far from Heartless". The Economist, Volume 365, December 14, 2002, p. 62-63.

Eilbert, H. and I.R. Parket (1973). The Current Status of Corporate Social Responsibility. Business Horizons, 16, August, pp. 5-14.

Epstein, E.M. (1987). The Corporate Social Policy Process: Beyond Business Ethics, Corporate Social Responsibility and Corporate Social Responsiveness. California Management Review, 29, pp. 19-114.8

Enderle, George (1999). International Business Ethics: Challenges and Approaches. University of Notre Dame Press.

Fliess, Barbara (2001). Better Business Behaviour. Observer, November, No. 229, pp. 53 55 .

Frederick, W.C. (1960). The Growing Concern over Business Responsibility. California Management Review, 2, Summer, pp. 54-61.

Friedman, M. (1970). The Social Responsibility of Business is to Increase its Profits. New York Times Magazine. September 13, 1970, pp. 122-126.

Frynas, Jedrzej George (2003). The Transnational Garment Industry in South and SonthEast Asia: a Focus on Labor Rights, p. 162-187 in Transnational Corporations and Human Rights, edited by Jedrzej George Frynas and Scott Pegg, Palgrave Macmillan Ltd.

Fryxell, G.E. and J. Wang (1994). The Fortune Corporation Reputation Index. Journal of Management. 20(1) pp. 1-14.

Gary, Ian and Terry Lynn Karl (2003). Bottom of the Bomrel: Africa's Oil Boom and the Poor. Catholic Relief Services. 
Gatewood, R.D., M. A. Gowan and G.J. Lauteenschlager (1993). Corporate Image, Recruitment Imoge and Initial Job Choice Decisions. Academy of Management Joumal 36(2) pp. 414-427.

Gereffi, Gary, Ronie Garcia-Johnson and Erika Sasser (2001). The NGO Industrical Complex, Foreign Policy, July/August, pp. 56-65.

Hosmer, L.T. (1994). Strategic Plonning as if Ethics Mattered, Strategic Management Joumal, 15, pp. 17-34.

IIED (2000). The Reality of Sustainable Trade, IIED 2000, editors: Nick Robins and Sarah Roberts.

ILO (1969). General Examination of Social Problems in the Leather and Footwear Industry - Tripartite Technical Meeting for the Leather and Footwear Industry, Geneva 1969 , ILO.

Johnston, Archie (1997). Business Ethics and Corporate Social Responsibility: A Strategic Competitive Advantage. Master of Business Administration, Faculty of Business Administration, Simon Fraser University.

Johnston, H.L. (1971). Business in Contemporary Society: Framework and Issues. Belmont, CA: Wadsworth.

Kapelus, Paul (2002). Mining, Corporate Social Responsibility and the "Community": The Case of Rio Tinto, Richards Bay Minerals and the Mbonambi, Journal of Business Ethics, 39, pp. 275-296.

Kapstein, Ethan B. (2001). The Corporate Ethics Crusade, Foreign Affairs, Volume 80, No. 5, pp. 105-119.

Kingston, Peter and Jay Wagner (2004). SuStainable and HSE/CSR Performance: The Role of Leadetship, The Seventh SPE International Conference on Health, Safety, and Environment in Oil and Gas Exploration and Production. Calgary, Aberta, Canada, 29-31 March 2004.

Klonoski R.J. (1991). Foundational Considerations in the Corporate Social Responsibility Debate. Business Horizons, 34(4), 9-18.

Kostova, T. and S. Zaheer (1999). Organizational Legitimacy under Conditions of Complexity: The Case of the Multinational Enterprise, Academy of Management Review, 24(1), pp. 64-81. 
Kotter, J.P. and I.L. Heskett (1992). Corporate Culture and Perfomance. The Free Press, New York, NY.

Lee, M. (1997). Responsible Business Development Through Community Economic Development and Corporate Social Responsibility, Burnaby, $\mathrm{BC}$ : CED Centre, Simon Fraser University.

Levitt, T. (1983). The Dangers of social Responsibility. In T.L. Beauchamp, \& N.E. Bowie (eds.) Ethical Theory and Business (pp.83-86). Englewood Cliffs, New Jersey: Prentice-Hall Inc.

MacDonald, Eleanor L.L. (1994) Vancouver City Sovings Credit Union: A Case Study in Corporate Social Responsibility in Financial Institutions. Master of Business Administration, Faculty of Business Administration, Simon Fraser University.

Macmillan, Steven (1996). Corporate Social Investments: Do they Pay? Journal of Business Ethics. Volume 15, no.3 - March. Kluwer Academic Publishers. Pp. 309-314.

McGuire, J., Sundgren, A., and Schneeweis, T. (1988). Corporate Social Responsibility and Firm Financial Performance. Academy of Management Joumal, 31 (4), 854-872.

McIntosh, M., Leipziger, D., Jones, K., and Coleman, G. (1998). Corporate Citizenship. London. GB: Pitman.

Organization for Economic Co-operation and Development (2001). Corporate Social Responsibility: Private Initiatives and Public Goals. . OECD Publications, 2, rue AndrePascal, 75775 Paris Cedex 16, France.

Organization for Economic Co-operation and Development (2001). Corporate Social Responsibility: Porthers for Progress. OECD Publications, 2, rue Andre-Pascal, 75775 Paris Cedex 16, France.

Overton, Cindy (2004). Corporate Social Responsibility - Capturing the Volue, The Seventh SPE International Conference on Health, Safety, and Environment in Oil and Gas Exploration and Production. Calgary, Alberta, Canada, 29-31 March 2004.

Petersen, Kurt (1994). The Maquila Revolution in Guatemala, in Global Production The Apparel Industry in the Pacific Rim, Temple University Press, Philadelphia.

Riordan, Christine M., Robert D. Gatewood and Jodi Barnes Bill. (1997). Corporate Image: Employee Reactions and Implications for Managing Corporate Social Performance. Jounal of Business Ethics. Vol. 16, no. 4, March. Kluwer Academic Publishers pp. 401-412. 
Robins, Donald P. and R. Eric Reidenbach (1989). Business Ethics: Where profits met value systems. Englewood Cliffs, New Jersey: Prentice Hall.

Roman, R., S. Hayibor and B. Agle (1999). The Relationship between Social and Financial Performance, Business and Society 38(1), pp.109-125.

Samuelson, Paul A. (1971). Love that Corporation, Mountain Bell Magazine, Spring 1971.

Schumacher, E.F. (1999). Small is Beautiful-Economics as if People Mattered, Hartley and Marks Publishers Inc.

Simms, Ronald R. (1994) Ethics and Organizational Decision Making. Westport, Connecticut: Quorum Books.

Stanwick, P. and Stanwich, S. (1998). The relationship between corporate social performance, and organizational size, financial performance, and environmental performance: An empirical examination. Journal of Business Ethics, 17, 195-204.

Stoecker, R. (1991). Evaluating and rethinking the case study. The Sociological Review, 39 , pp. 88-112.

Thompson, A.A. Jr. and A.J. Strickland (1994). Direccion y Administracion Estrategicas: Conceptos, Casos y Lecturas, (Addison, Wesley, USA).

TVNews MSNBC. Now and Then Time Line. (Internet).

Velazquez, M.G. (1983). Why Corporations are not Morally Responsible for Anything they do. Business and Professional Ethics Journal, 2(3), 1-18.

Waddock, S.A. and S.B. Graves ((1997). The Corporate Social Performance-Financial Link, Strategic Management Joumal, 18, pp. 303-319.

Wawryk, Alex (2003). Regulating Transhational Corporations through Corporate Codes of Conduct, p. 53-78 in Transnational Corporations and Human Rights, edited by Jedrzej George Frynas and Scott Pegg, Palgrave Macmillan Ltd.

Wesley, Cragg (1997). Teaching Business Ethics. The Role of Ethics in Business and in Business Education. Joumal of Business Ethics. Vol. 16, no. 3, February, Kluwer Academic Publishers, pp. $231-245$.

Wheeler, David, Heike Fabig and Richard Boele (2002). Parcoloxes and Dilemas for Stakeholder Responsive Firms in the Extractive Sector: Lessons from the Case of Shell and the Ogoni. Journal of Business Ethics. Vol. 39, pp. 297-318. 
Williams, Bob (2002). Oil Industry Adapting to Evolving New Paradigm on Corporate Govemance, Accountability, Oil and Gas Joumal, October 28, pp.20-32.

Wilson, A. (1997). Business and its social responsibility, In Davies, P. (Ed), Current Issues in Business Ethics, pp. 50-60. London, GB: Routledge.

Wilson, Ian (2000). The New Rules of Corporate Conduct-Rewriting the Social Charter. Copyright @ 2000 by Ian Wilson. Quorum Books, Westport, CT - Greenwood Publishing Groups, Inc.

Winnie, W. Lai (1999). Corporate Social Responsibility and Performonce: A Stakeholder Approach. Master of Business Administration. Faculty of Business Administration. Simon Fraser University.

Wokutck, Richard E and Barbara A Spenser (1987). Corporate Saints and Simners. California Management Review, 29 Winter, pp. 62-77.

Wood, D.J. (1991). Towards Improving Corporate Social Performance. Business Horizons, 34(4), 66-73.

Yin, Robert K. (1994). Case Study Research -- Design and Methods. SAGE Publications. 


\section{Internet Resources}

\begin{tabular}{|c|c|}
\hline Wo6rile & 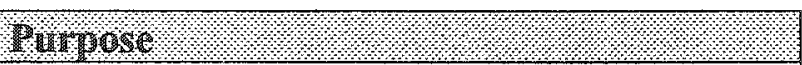 \\
\hline Www.csiforum.com & $\begin{array}{l}\text { An international educational charity } \\
\text { established to promote responsible business } \\
\text { practices intemationally to achieve social, } \\
\text { economic and environmentally sustainable } \\
\text { development. }\end{array}$ \\
\hline www.rc-sdbp.org & $\begin{array}{l}\text { A consortium of UK based organizations } \\
\text { aimed at engaging business more effectively } \\
\text { and systematically in poverty elimination. }\end{array}$ \\
\hline $\begin{array}{l}\text { www.oecd.org/EN/document/O, EN- } \\
\text { document-76-3-no-12-36547-0,00.html }\end{array}$ & $\begin{array}{l}\text { OECD website and report on } \\
\text { recommendations to improve corporate } \\
\text { governance. }\end{array}$ \\
\hline $\begin{array}{l}\text { www.catholicrelieforg/get involved/advo } \\
\text { cacy/policy_and_strategic_issues/oil_repor } \\
t \text { full.pdf }\end{array}$ & $\begin{array}{l}\text { Report on "publishing what you pay" by } \\
\text { Catholic Relief Services aimed at the oil and } \\
\text { gas industry. }\end{array}$ \\
\hline www.dti.gov.uk/support/responsibility.htm & $\begin{array}{l}\text { The UK Department of Trade and Industry } \\
\text { (DTI) website. }\end{array}$ \\
\hline www.dti.gov.uk/sustainability & $\begin{array}{l}\text { The UK Department of Trade and Industry } \\
\text { (DTI) website on sustainable development and } \\
\text { the environment. }\end{array}$ \\
\hline www.dti.gov.uk/worldtrade/ukncp.htm & $\begin{array}{l}\text { A UK website of National Contact Points for } \\
\text { the OECD Guidelines for Multinational } \\
\text { Enterprises. The site contains information on } \\
\text { the guidelines adhering countries and other } \\
\text { national contact points. }\end{array}$ \\
\hline www.societyandbusiness.gov.uk & $\begin{array}{l}\text { A forum for people to feed in their views on } \\
\text { the direction that the UK government should } \\
\text { be taking on CSR activities. It provides } \\
\text { examples of good business practice, gives } \\
\text { sources of information and advice and } \\
\text { provides a single point of entry into the full } \\
\text { range of government activity on CSR. }\end{array}$ \\
\hline www.globalreporting.org & $\begin{array}{l}\text { The website for the Global Reporting Initiative } \\
\text { (GRI) a multi-stakeholder process and } \\
\text { independent institution whose mission is to } \\
\text { develop and disseminate globally applicable } \\
\text { sustainable reporting guidelines. GRI is a } \\
\text { collaborating center of the United Nations } \\
\text { Environment Program (UNEP). }\end{array}$ \\
\hline Www.wbcsd.org & $\begin{array}{l}\text { The World Council for Sustainable } \\
\text { Development website, a coalition of } 165\end{array}$ \\
\hline
\end{tabular}




\begin{tabular}{|c|c|}
\hline & $\begin{array}{l}\text { international companies united by a shared } \\
\text { commitment to sustainable development via } \\
\text { the } 3 \text { pillars of economic growth, ecological } \\
\text { balance and social progress. }\end{array}$ \\
\hline WWW.cbsr.ca & $\begin{array}{l}\text { Home page of the Canadian Business for } \\
\text { Social Responsibility (CBSR). The goal of } \\
\text { CBSR is to support business in their effort to } \\
\text { implement higher standards of social and } \\
\text { environmental responsibility for Canadian } \\
\text { corporations. }\end{array}$ \\
\hline www.corporate-accountability.ca & $\begin{array}{l}\text { NGO initiative spearheaded by Ed Broadbent } \\
\text { in Canada. The Canadian Democracy of } \\
\text { Corporate Accountability Commission } \\
\text { Website aims at developing concrete measures } \\
\text { that address issues of corporate accountability. } \\
\text { The commission is hosted by the Arthur } \\
\text { Kroeger College of Public Affairs, Carleton } \\
\text { University. }\end{array}$ \\
\hline www.iled.org & $\begin{array}{l}\text { The International Institute for Environment } \\
\text { and Development, an independent non-profit } \\
\text { organization promoting sustainable patterns of } \\
\text { world development through collaborative } \\
\text { research, policy studies, networking and } \\
\text { knowledge dissemination. }\end{array}$ \\
\hline www.unglobalcompact.org & $\begin{array}{l}\text { UN Global Compact website. Information on } \\
\text { dialogue between corporations, UN agencies } \\
\text { and civil society. }\end{array}$ \\
\hline WWW.cemefi.org & $\begin{array}{l}\text { Mexican Center on Philanthropy - provides } \\
\text { businesses and non-profits, non-partisans } \\
\text { organizations information and resources on } \\
\text { philanthropy, volunteerism and other aspects } \\
\text { of community investment. }\end{array}$ \\
\hline Www.csreurope.org & $\begin{array}{l}\text { A business driven membership network to help } \\
\text { companies achieve proftability, sustainable } \\
\text { growth and human progress by placing CSR in } \\
\text { the mainstream of business practice. }\end{array}$ \\
\hline www.bc.edu./bc org/aup/csom/cec & $\begin{array}{l}\text { Boston College Center for Corporate } \\
\text { Citizenship Organization established to } \\
\text { strengthen business corporate community } \\
\text { programs. }\end{array}$ \\
\hline www.bsr.org & $\begin{array}{l}\text { Business for Social Responsibility helps } \\
\text { companies achieve success in ways that } \\
\text { respect ethical values, people, communities, }\end{array}$ \\
\hline
\end{tabular}




\begin{tabular}{|c|c|}
\hline & and the enviromment. \\
\hline www.bitc.org.uk & $\begin{array}{l}\text { Business in the Community - established to } \\
\text { inspire businesses to increase the quality and } \\
\text { extent of their contribution to social and } \\
\text { economic regeneration. }\end{array}$ \\
\hline www.ccp.ca & $\begin{array}{l}\text { Center for corporate philanthropy - promotes } \\
\text { corporate giving, volunteering and support for } \\
\text { the community by building partnerships } \\
\text { between the private sector and charitable } \\
\text { organizations. }\end{array}$ \\
\hline www.conference-board.org & $\begin{array}{l}\text { Through its global corporate citizenship } \\
\text { program it conducts research and works with } \\
\text { international companies on a wide range of } \\
\text { issues. Its purpose is to improve the business } \\
\text { enterprise system and to enhance the } \\
\text { contribution of business to society. In Canada } \\
\text { it is located at } 255 \text { Smyth Road, Ottawa, } \\
\text { Ontario K1H } 8 \mathrm{M} 7 \text {, Tel: (613) 526-3280 }\end{array}$ \\
\hline www.cof.org & $\begin{array}{l}\text { Council of foundations provides services to } \\
\text { companies, including newsletters, publications, } \\
\text { library and one to one technical assistance. }\end{array}$ \\
\hline www.fdncenter.org & $\begin{array}{l}\text { The foundation center is an information- } \\
\text { clearing house that collects, organizes and } \\
\text { disseminates information on foundations, } \\
\text { corporate giving and related subjects. }\end{array}$ \\
\hline Www.gife.org.br & $\begin{array}{l}\text { Group of Institutes, Foundations, and } \\
\text { Companies in Brazil. Its mission is to improve } \\
\text { and disseminate the concept and practices of } \\
\text { using private resources for the development of } \\
\text { common good. }\end{array}$ \\
\hline www. worldcsr.com & $\begin{array}{l}\text { This site links together the sites of } \\
\text { organizations around the world working on } \\
\text { CSR. }\end{array}$ \\
\hline Www.ftse.com & $\begin{array}{l}\text { Model for best corporate responsibility } \\
\text { practices. }\end{array}$ \\
\hline $\begin{array}{l}\text { www. sustainability- } \\
\text { index.com/djsi pdf/publications/presentati } \\
\text { ons/DISI PRT } 030904 \text { review.pdf }\end{array}$ & $\begin{array}{l}\text { Dow Jones sustainability indexes annual } \\
\text { review for } 2003 \text {. }\end{array}$ \\
\hline $\begin{array}{l}\text { WWW. sustainability- } \\
\text { index.com/htmle/publicatiohns. studies.htm }\end{array}$ & $\begin{array}{l}\text { Report "Changing Oil: Emerging } \\
\text { Environmental Risks and Shareholder Value in } \\
\text { the Oil and Gas industry". }\end{array}$ \\
\hline $\begin{array}{l}\text { WwW.europa.eu.int/comm/employment so } \\
\text { cial/soc-dial/csr/greenpaper.htm }\end{array}$ & $\begin{array}{l}\text { Commission for the European Communities; } \\
\text { paper on promoting corporate social }\end{array}$ \\
\hline
\end{tabular}




\begin{tabular}{|c|c|}
\hline & responsibility in Europe. \\
\hline Www.theebi.org & $\begin{array}{l}\text { Home page includes a report which provides } \\
\text { practical guidance on how biodiversity issues } \\
\text { can be integrated into upstream oil and gas } \\
\text { industry activities. }\end{array}$ \\
\hline www.unglobalcompact.org & The UN Global Compact website \\
\hline www.ifc.org & $\begin{array}{l}\text { The IFC website. Information on sustainability } \\
\text { and measurements can be found in this } \\
\text { website. }\end{array}$ \\
\hline www.equator-principles.com & $\begin{array}{l}\text { Set of environmental and social screening } \\
\text { criteria applied to large capital projects. The } \\
\text { focus is on developing countries. }\end{array}$ \\
\hline
\end{tabular}


APPENDIX 1

RESEARCH STUDY PROCESS 


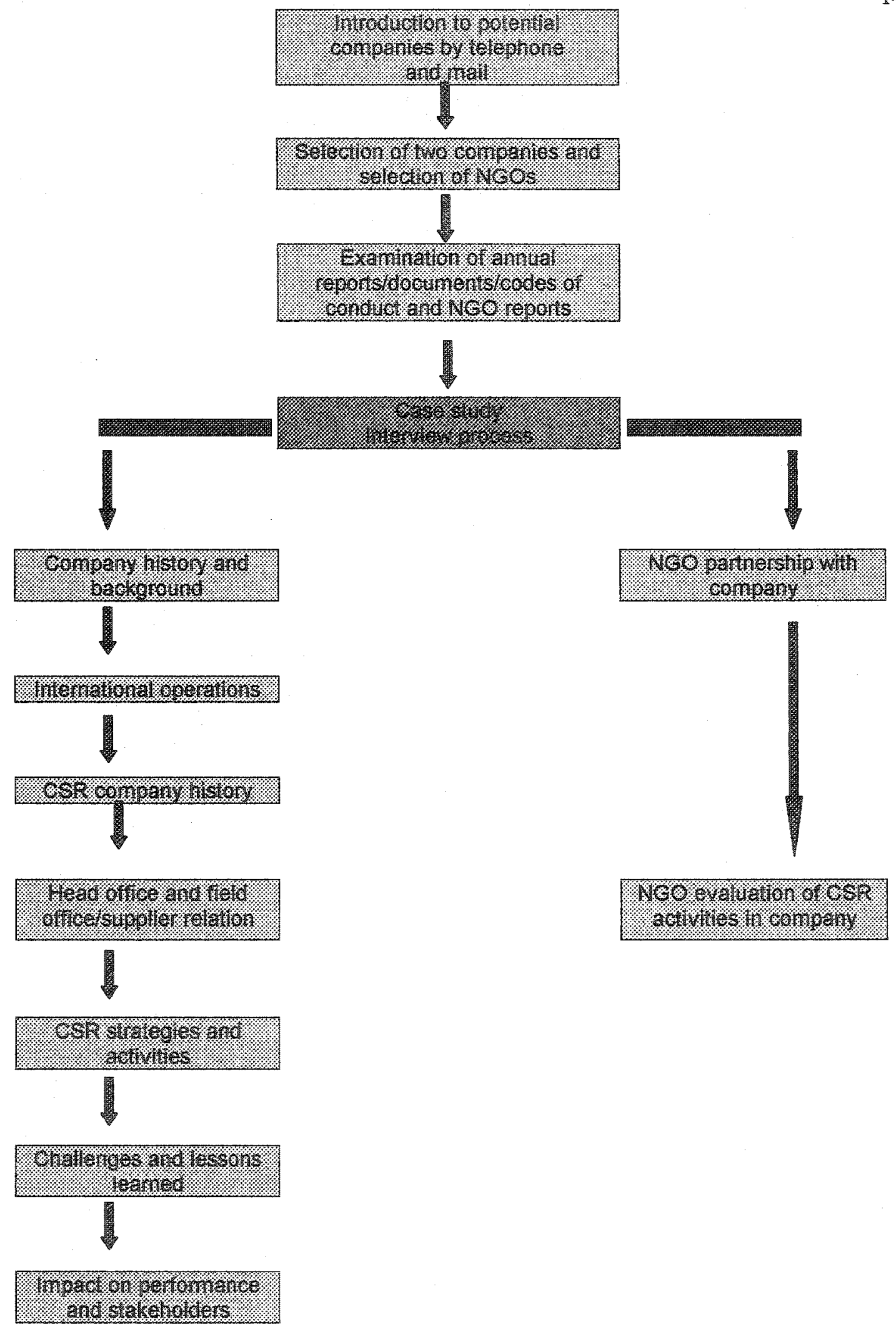




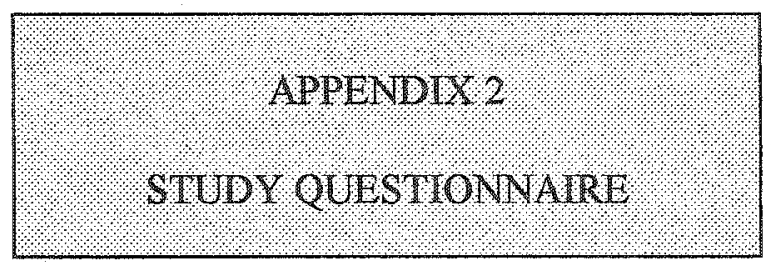




\section{Questionalire for Company Representatives}

The following questionnaire was used to guide the researcher. The interviewees were asked to elaborate on their answers, explain why a certain approach was taken, the results, etc. This questionnaire was adapted from the original one presented in the proposal once the companies had been selected and after the initial evaluation of the company's secondary data (company reports and documentation, website, etc.), since some of these questions were answered during the secondary data evaluation and were no longer relevant.

\section{CSR Situation in the Company}

1. Do you have a company policy and strategy on CSR? When was this formalized?

2. Does your company have guidelines on the following issues?

- General business ethics

At corporate level At the field level

- Responsibilities towards customers

e.g.

fair trading practices

fair marketing practices

product safety

service

other (please specify)

- Responsibilities towards employees

e.g. equal opportunities

health and safety

preference towards local/community employees

developing skills

developing personal skills

employment security

other (please specify)

- Responsibilities towards suppliers

e.g. purchasing ethics

preference towards local suppliers

social consciousness

environmental consciousness

other (please specify)

- Responsibilities towards the broader community

e.g. sustainability of community

community investment/philanthropy

community consultation

other (please specify) 
- Responsibilities towards the environment

e.g. pollution

energy usage

use of non-renewable resources

urban renewal

other (please specify)

Please specify if your company has any other CSR guidelines.

3. Does your company have an individual or department responsible for CSR? Please describe the CSR department and position in the organizational structure. Who does this person or department report to? When was the department created?

4. What are your CSR programs and activities? Any philanthropy? Which are your areas of concentration on CSR e.g. employee, clients, environment, suppliers, etc.

5. Do you have a budget and annual expenditure plan for CSR at both the corporate and field level?

6. How are the funds allocated? Board level, public affairs department, CSR department, staff committee, etc.

7. What would you say are some of the key success factors for CSR at the macro corporate level and at the project micro level?

\section{Accountability and transparency}

1. Is there a named, or are there named senior members who take full responsibility for CSR issues, are they held responsible?

2. Is there an accountability system whereby each department has named an individual or individuals to be accountable? E.g. producing reliable information, etc.

3. Do you have a social/environmental reporting system?

4. What method of reporting do you use? Written, oral, through meetings, discussions, internet, etc.

5. Do you have a social and environmental audit?? Who does your social and environmental audit? Is it done internally or externally? Explain what method is used and why.

6. Do you subscribe to any relevant international and national charters, codes of conduct, guidelines, etc.

8. Does your company have codes of conduct/ certification and regulations?

9. If yes, please answer the following? Are these done in internally or are the certificates from NGOs, industry or multilateral organizations.

10. How often is this done? Who is this sent to?

\section{Suppliers and Clients}

1. Does your company have any special policies or strategies for working with suppliers and clients? Is this applied at the corporate and field level?

2. Do you have effective systems to listen to customers?

3. In regards to your suppliers, do you have any supplier audits? 
4. Could you please explain what programs or activities you have with suppliers and clients?

\section{Environment}

1. Does your company have any special policies or strategies regarding the environment?

2. Does your company have a system to monitor and alert on environmental issues?

3. What type of programs, activities or initiatives you have regarding the environment?

\section{Employees}

1. Does your company have policies regarding equal opportunities, racial discrimination, safety, etc?

2. Do you offer training or briefing on company values?

3. How does your company manage employee issues, is this done through the human resource or CSR department?

4. What activities do you have with employees? Community volunteering? Equal opportunities, skill training, etc.

5. Could you please elaborate on local employees and initiatives undertaken by your company?

6. Does your company have affirmative action measure for women, minorities, etc. Please explain what measure are taken. E.g. quotas, daycare, promotion, flexible hours, etc.

\section{Commumity}

1. Who implements your community activities?

2. Does your company recognize indigenous people and their tradition or customary ownership of land?

3. Do you hold consultations with the communities?

4. Do you have any details to provide on your community program?

5. Type of activities you have for the community? Define and explain range of activities? Focus areas?

6. How were the programs developed? Was there a sudy done to detemine community needs?

7. Did you develop any monitoring mechanism or indicators to determine results of investment on the community?

8. How ofen is monitoring done?

9. Do you have any parameters to determine success of investment?

\section{Monitoring}

1. Do you make any form of assessment of the social/economic/environmental impact of your product/services? 
2. Do you have indicators for all your focus areas?

3. In your opinion, is there a correlation between company performance and investment in CSR?

4. How do you measure impact on the communities, environment, employees, etc?

\section{Lessons Learmed}

1. Please provide any lesson learned on CSR, by your stakeholder group: employees, environment, supplier, customer, community, etc... The lesson learned should focus not on stating a problem but identifying what works and what doesn't work.

2. What challenges do you face in your company to "sell" the idea of CSR? How do you make the business case for CSR?

3. What do you consider to be the most significant challenge or constraint facing those responsible for CSR?

4. What is the relationship between corporate CSR and field CSR? Do you have different policies and strategies regarding CSR?

5. Do you have any CSR innovations to share. 


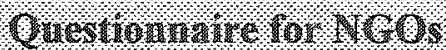

The following questionnaire was used to guide the researcher. The purpose of consulting with NGOs was to determine what was the perception of NGOs in regards to the CSR activities undertaken by the company.

1. In what capacity do you work with the company?

2. Could you elaborate on the type of activities funded by the company.

3. In your opinion, have these activities and/or programs been successful?

4. Do you have any lesson learned regarding CSR activities, initiatives and programs?

5. Room for improvement?

6. Have you worked with other companies doing CSR activities? 